\title{
COMMENTS
}

\section{Community Resistance to School Desegregation: Enjoining the Undefinable Class}

Federal district courts have often faced serious community resistance to the implementation of desegregation judgments, most recently to those decrees that require busing as a means of achieving unitary school systems. Almost twenty years ago the Supreme Court declared that resistance from the community would not be allowed to frustrate the implementation of the constitutional requirement that school segregation be abolished. ${ }^{1}$ Since then, the federal courts have consistently affirmed this commitment, employing a panoply of substantive and procedural powers to enforce the mandate announced in Brown v. Board of Education. ${ }^{2}$ A recent judicial response to community resistance has been to issue orders designed to prevent entire communities from engaging in specified activities. ${ }^{3}$ Some courts have even proscribed in general terms all conduct that may unduly interfere with the implementation of a desegregation decree. ${ }^{4}$

I "The constitutional rights of respondents are not to be sacrificed or yielded to . . . violence and disorder . . . ." Cooper v. Aaron, 358 U.S. 1, 16 (1958).

2347 U.S. 483 (1954); 349 U.S. 294 (1955).

${ }^{3}$ E.g., Morgan v. Hennigan, 379 F. Supp. 410 (D. Mass.) (Boston schools found segregated and remedial plans ordered), aff'd sub nom. Morgan v. Kerrigan, 509 F.2d 580 (1st Cir. 1974), cert. denied, 421 U.S. 963 (1975), desegregation plan ordered, 401 F. Supp. 216 (D. Mass. 1975), orders issued, No. 72-911-G (D. Mass., Sept. 5, 1975; Dec. 17, 1975) (orders requiring measures to protect decree from community resistance), desegregation plan aff'd, 530 F.2d 431 (1st Cir. 1976); Newburg Area Council, Inc. v. Board of Educ., 489 F.2d 925 (6th Cir.) (reversing district court to find segregation in three school districts in county), vacated and remanded, 418 U.S. 918 (1973), opinion reinstated with modifications, 510 F.2d 1358 (6th Cir. 1974), cert. denied, 421 U.S. 931 (1975), mandamus issued, 521 F.2d 578 (6th Cir. 1975) (consolidating actions and requiring approval of plan for desegregation of new county-wide school district for coming school year), orders issued, Nos. 7045 \& 7291 (W.D. Ky., July 30, 1975; Sept. 2, 1975; Sept 6, 1975) (orders requiring measures to protect decrees from community resistance); see notes 22 \& 26 infra; Mims v. Duval County School Bd., 338 F. Supp. 1208 (M.D. Fla. 1971), supplemented, 350 F. Supp. 553 (1972), contempt citation aff'd., United States v. Hall, 472 F.2d 261 (5th Cir. 1972); Lynch v. Snepp, 350 F. Supp. 1134 (W.D.N.C. 1972), rev'd on other grounds, 472 F.2d 769 (6th Cir. 1973), cert. denied, 415 U.S. 983 (1974).

' E.g., Kasper v. Brittain, 245 F.2d 92, 94 (6th Cir.), cert. denied, 355 U.S. 834 (1957) ("in any way interfering with the carrying out of the court's order"); Mims v. Duval County School Bd., 338 F. Supp. 1208 (M.D. Fla. 1971), supplemented, 350 F. Supp. 553, 554 (1972) ("any other act to disrupt the orderly operation of Oceanway School"); Stell v. Board of Educ., No. 1316 (S.D. Ga. March 16, 1972) ("interfering with the plan of desegregation"); 
The purpose of this comment is to examine the legitimacy of these "community injunctions" as a means of ensuring the implementation of school desegregation decrees. The comment first discusses the enforcement problems peculiar to school desegregation judgments, then describes and evaluates existing methods of enforcing desegregation judgments against community resistance in order to determine the need for community injunctions as an additional enforcement technique. In light of that discussion, recent enforcement orders are examined to determine their legal status and comparative effectiveness as methods of enforcement. The comment concludes that, notwithstanding the courts' real need for potent weapons to enforce their desegregation judgments, the enforcement problems of school desegregation cannot justify the use of orders that directly or indirectly prohibit interference from the community at large.

\section{Enforcement Problems of School Desegregation}

\section{A. Community Resistance}

In the decades since Brown, federal district courts have dealt with two recurring problems in implementing school desegregation decrees. First, courts have had to devise ways of meeting changing forms of resistance by state and local governments to the requirement that dual school systems be abolished. ${ }^{6}$ Second, courts have faced widespread, sometimes violent, community resistance to court-ordered desegregation. ${ }^{7}$ Unlike most injunctive decrees, which

Stanley v. Darlington County School Dist., 313 F. Supp. 439, 440 (D.S.C. 1970) ("individually or collectively interfere with the operation of the public schools").

s "Community injunctions" refer to court orders that seek to control the conduct of an entire community, either directly by orders addressed to "all persons" or indirectly by orders addressed to local officials.

- The history of attempts to evade or limit this requirement and judicial responses to such attempts have been treated in detail elsewhere. See, e.g., Fiss, The Fate of an Idea Whose Time Has Come: Anti-Discrimination Law in the Second Decade after Brown v. Board of Education, 41 U. CHI. L. Rev. 742, 752-58 (1974); Read, Judicial Evolution of the Law of School Integration Since Brown v. Board of Education, 39 LAw \& ConTEMP. ProB. 7 (1975); Note, Schools, Busing, and Desegregation: The Post-Swann Era, 46 N.Y.U.L. Rev. 1078, 1083-90 (1971).

7 See, e.g., W. ReCord \& J. Record, LITTLE Rock, U.S.A. (1960) (discussing the violent response to school desegregation in Little Rock in 1957); Kasper v. Brittain, 245 F.2d 92 (6th Cir. 1957), cert. denied, 355 U.S. 834 (1957), discussed in Murphy, The Contempt Power of the Federal Courts, 18 FED. B.J. 34, 40-41 (1958). Recent examples of civil unrest in response to desegregation have occurred in Boston and Louisville, Kentucky. See, e.g., Newburg Area Council, Inc. v. Board of Educ., Nos. 7045 \& 7291 (W.D. Ky., Sept. 6, 1975); Morgan v. Kerrigan, 401 F. Supp. 216, 224-25 (D. Mass. 1975) (describing the violence surrounding the implementation of busing plans). 
impose legal restraints and duties on a minority of the community, school desegregation orders are effectively "imposed" on entire communities, requiring the affirmative involvement and the cooperation of many persons who were not parties to the litigation. This is particularly true of plans that alter school attendance zones or that require two-way busing. Furthermore, court-ordered desegregation often evokes intense reactions from many different sectors of a community. These characteristics make desegregation decrees particularly vulnerable to disruption and delay by an "undefinable class" of individuals who are neither parties to the litigation nor legally related to parties. ${ }^{8}$

Community resistance can take several forms, some of which are beyond the present scope of courts' remedial powers. The phenomenon of "white flight," perhaps the most serious long-term obstacle to achieving desegregated school systems, cannot be controlled by a desegregation court. ${ }^{9} \mathrm{~A}$ form of resistance that courts may be able to remedy is a refusal to cooperate with a desegregation order by, for example, refusing to send a child to his newly assigned school while keeping him in the public school system. ${ }^{10}$ Another form of resistance is nonviolent conduct that seeks to obstruct the implementation of desegregation indirectly. This form of resistance is the most troubling to courts in the short run, for although it threatens the successful enforcement of the decree, it may not be susceptible to the techniques available to confront the problems of direct or violent obstruction of the decree. For example, speech in public places that does not present an imminent danger of inciting lawless conduct may still threaten the peaceful implementation of desegregation by intimidating the participants in a busing program or by arousing community resentments which may develop into resistance to the desegregation plan. ${ }^{11}$ Conduct not involving speech

* United States v. Hall, 472 F.2d 261, 266 (5th Cir. 1972); Rendleman, Beyond Contempt: Obligors to Injunctions, 53 Texas L. REv. 873, 918 (1975).

- The impact of school desegregation cannot be minimized by compromising a decree so that whites who might flee if there were complete desegregation will remain in the school district. See United States v. Scotland Neck City Bd. of Educ., 407 U.S. 484 (1972). Conversely, a desegregation plan cannot be expanded to an interdistrict remedy solely because whites have already left the central city and will continue to do so. See Milliken v. Bradley, 418 U.S. 717 (1974). Population shifts subsequent to the implementation of a desegregation decree do not justify annual readjustments of the decree. See Pasadena City Bd. of Educ. v. Spangler, 96 S. Ct. 2697 (1976).

to Board of Educ. v. York, 429 F.2d 66 (10th Cir. 1970), cert. denied, 401 U.S. 954 (1971).

"See Newburg Area Council, Inc. v. Board of Educ., Nos. 7045 \& 7291 (W.D. Ky., July 30,1975 ; Sept. 2, 1975) (orders prohibiting all "profane" protest and restraining the Safety Director from issuing parade permits and creating a "Hyde Park speakers corner" in the county fairgrounds parking lot on the outskirts of the city). On September 6, the court 
may also present such a latent threat to orderly enforcement. ${ }^{12}$

\section{B. Recent Judicial Response to Community Resistance}

Faced with community resistance to the implementation of their desegregation decrees, several district courts have responded with detailed sets of orders designed to deal with the problem. In 1971 the district court in Mims v. Duval County School Board ${ }^{13}$ ordered the desegregation of Jacksonville's school system according to a plan consistent with the Supreme Court's decision in Swann v. Charlotte-Mecklenburg Board of Education. ${ }^{14}$ After the implementation of the desegregation order, which required the pairing and clustering of previously segregated schools, racial unrest and violence developed at Ribault High School. ${ }^{15}$ Racial tensions forced the closing of the school on one occasion. The Superintendent of Schools and the Sheriff of Jacksonville petitioned for injunctive relief, seeking to restrain outsiders from interfering with the operation of the school. The district court, acting ex parte, granted the requested relief." ${ }^{16}$ The order applied to "all Ribault Senior High School students and any person acting independently or in concert with them and having notice of this order." 17 Violation of the order by unauthorized entry onto the school grounds was the subject of a contempt citation that was affirmed in United States $v$. Hall. ${ }^{18}$

abolished "all protest areas" around the schools and directed the jamming of citizens' band radio channels because they had been "utilized by unlawfully acting protesters to prevent the implementation of our desegregation order of July 30, 1975." See note 22 infra.

These enforcement orders may well infringe first amendment rights. See Brandenburg v. Ohio, 395 U.S. 444 (1969) (advocacy that does not present an imminent and likely danger of inciting lawless conduct is protected by the first amendment); Schneider v. State, 308 U.S. 147,163 (1939) (the exercise of speech in appropriate places cannot be abridged on the excuse that it may be exercised in some other place). This comment will not examine the scope of first amendment protections as a substantive limit on the authority of courts to regulate resistance to school desegregation. The procedures for issuing orders regulating such resistance have first amendment implications that are discussed at text and notes at notes 198-211 infra.

12 For example, both the Louisville and Boston courts prohibited assemblies of small groups of persons along bus routes "while school buses are being operated along them." Newburg Area Council, Inc. v. Board of Educ., Nos. 7045 \& 7291 (W.D. Ky., Sept. 6, 1975); Morgan v. Kerrigan, No. 72-911-G (D. Mass., Sept. 5, 1975).

13329 F. Supp. 123 (M.D. Fla.), aff'd, 447 F.2d 1330 (5th Cir. 1971).

14 402 U.S. 1 (1971). For the history of the litigation concerning the desegregation of the Duval County schools, see United States v. Hall, 472 F.2d 261, 262 (5th Cir. 1972); Board of Public Instruction v. Braxton, 402 F.2d 900, 902-03 (5th Cir. 1968).

is For a summary of the situation that followed the desegregation order, see Mims v.

Duval County School Bd., 338 F. Supp. 1208, 1209 (M.D. Fla. 1971).

"Id.

17 Id. (emphasis added).

1* 472 F.2d 261 (5th Cir. 1972). 
Louisville, Kentucky began county-wide busing for desegregation in the fall of 1975 . The district court encountered serious, sometimes violent community resistance to the busing plan. ${ }^{19}$ This resistance was not confined to racial tensions and violence in the schools, but extended to the community at large, which more than once had erupted into mob action. In Newburg Area Council, Inc. v. Jefferson County Board of Education, ${ }^{20}$ District Judge Gordon employed orders nearly identical in form to those used in Mims. The majority of the enforcement orders issued in Newburg Area Council were directed, as in Mims, to the community at large, ${ }^{21}$ and focused on directly controlling resistance to the desegregation decree. ${ }^{22}$ How-

1 For Judge Gordon's description of violent obstruction of his decrees, see Newburg Area Council, Inc. v. Board of Educ., Nos. 7045 \& 7291 (W.D. Ky., Sept. 6, 1975) (ordering safety and discipline measures).

20 Newburg Area Council, Inc. v. Board of Educ., 489 F.2d 925 (6th Cir.), vacated and remanded, 418 U.S. 918 (1973), opinion reinstated with modifications, 510 F.2d 1358 (6th Cir. 1974), cert. denied, 421 U.S. 931 (1975), mandamus issued, 521 F.2d 578 (6th Cir. 1975).

"E.g., Newburg Area Council, Inc. v. Board of Educ., Nos. 7045 \& 7291 (W.D. Ky., Sept. 6, 1975; Aug. 21, 1975) ("no person shall" and "any person destroying"). See also Stell v. Board of Educ., No. 1316 (S.D. Ga., March 16, 1972) ("all individuals regardless of race, creed, or age").

${ }^{22}$ In his initial order of July 30,1975 , attached to the desegregation decree, Judge Gordon placed the following restraints on private conduct:

1. Those persons wishing to protest the court's judgment . . . may employ signs or placards, or voice, so long as their actions are not violent, are not profane, and are not threatening in nature, and provided further; that those persons occupy the protest areas to be designated and defined at each school by the United States Marshal in charge, or the police officers in attendance. . . .

....

5. No person shall by the use of any automobile, or otherwise, attempt to block or impede the authorized flow of traffic in, to, or from any school building property; nor shall any person, not authorized by his official position, attempt to enter upon or board any school bus either to place thereon or remove therefrom any enrolled student; nor shall any person threaten to or impede the right of any enrolled student to walk to, from, or into, any school facility when said student is about the business of attending school or walking in return to his home following school hours. Violations hereof will subject one to federal custody and federal enforcement proceeding.

6. No person shall interfere with, nor cause threats to be made, or unlawful pressures to be exerted, against any employee of the school system or members of their families, or school board member, or volunteer, intended or directed toward the prevention of the performance of their official duty by them, or intended in any manner to prevent their carrying out and complying with the desegregation judgment and plan of this Court.

Newburg Area Council, Inc. v. Board of Educ., Nos. 7045 \& 7291 (W.D. Ky., July 30, 1975). The order of September 6, 1975 added additional restraints, providing that:

1. All protest areas are hereby abolished.

2. No persons shall assemble in or near any public school building not authorized by the school authorities.

3. Persons, more than three in number, shall not gather or assemble along any bus route in this . . . county while school buses are being operated along them.

Any person having notice of this order who violates any of the terms hereof shall be 
ever, the Newburg Area Council orders were novel in two respects. First, the orders were issued by the court sua sponte rather than in response to petitions from either local officials or parties to the desegregation suit. Second, Judge Gordon attempted to exercise indirect control over the community by ordering local officials to prevent or regulate certain conduct. ${ }^{23}$

In 1974 Boston's school system began busing in compliance with the desegregation judgment in Morgan $v$. Kerrigan. ${ }^{24}$ The district court met very serious and widespread community hostility and resistance to the enforcement of the busing plan. In response Judge Garrity joined local officials as defendants in the Morgan $v$. Kerrigan litigation. ${ }^{25}$ These officials were bound to the court's 1975 "Orders Concerning Security." By ordering these city officials to regulate the conduct of private persons, the court sought to exercise indirect control over the entire community. ${ }^{26}$

These two types of enforcement orders, direct and indirect, will

subject to arrest, prosecution and punishment, by imprisionment [sic] or fine or both for criminal contempt of this court under the laws of the United States of America.

Newburg Area Council, Inc. v. Board of Educ., Nos. 7045 \& 7291 (W.D. Ky., Sept. 6, 1975). Paragraph 3 of the order was voided on August 31, 1976.

${ }^{23}$ Several orders were directed to officials for the purpose of regulating private citizens' conduct. E.g., Newburg Area Council, Inc. v. Board of Educ., Nos 7045 \& 7291 (W.D. Ky., Sept. 2, 1975; Sept. 6, 1975) (first ordering the Safety Director of the city of Louisville to issue parade permits only for gatherings in a large open area away from the city and then ordering a member of the board of education to "jam" all citizens" band radio channels in the area to prevent their use in organizing protests against the desegregation order).

2s Morgan v. Hennigan, 379 F. Supp. 410 (D. Mass.), aff'd sub nom. Morgan v. Kerrigan, 509 F.2d 580 (1st Cir. 1974), cert. denied, 421 U.S. 963 (1975), desegregation plan ordered, 401 F. Supp. 216 (D. Mass. 1975), aff'd, 530 F.2d 431 (1st Cir. 1976).

25 Joined as "city defendants" were "the Boston School Committee, Superintendent and Mayor and their agents, servants, employees and attorneys." Morgan v. Kerrigan, No. 72911-G (D. Mass., Sept. 5, 1975). The court's orders also required the cooperative efforts of "the Boston Police, in collaboration with Massachusetts State Police, Metropolitan District Commission Police and United States Marshals and Deputy Marshais."

26 The orders require the city defendants to "see to it" that the police prohibit the following conduct:

(a) all gatherings of three or more people and all noisy or threatening conduct including picketing within 100 yards of the premises of any public school building which are likely to disrupt classwork or extracurricular programs or make students or teachers reasonably fearful for their safety as they arrive or depart from school; and

(b) all gatherings of three or more people engaged in or threatening to engage in violent conduct on or adjacent to any school bus or MBTA route or loading or unloading area used for the purpose of transporting students or used by students walking to or from public schools which make students or bus drivers reasonably fearful for their safety while en route to or from school or damage the vehicle in which students are riding or impede its progress.

Morgan v. Kerrigan, No. 72-911-G (D. Mass., Sept. 5, 1975). In its order of December 17, 1974, the court also ordered the School Committee and Superintendent to promulgate and enforce school discipline codes prohibiting students from communicating racial slurs or epithets. 
be examined as to their legitimacy and efficacy. This assessment will be made in light of the various alternative methods courts can use to enforce school desegregation judgments.

\section{Methods of Enforcing School Desegregation Judgments}

\section{A. Criminal Laws and Local Ordinances}

1. State Criminal Laws and Local Ordinances. The most immediately threatening manifestations of resistance to desegregation judgments typically violate state criminal laws dealing with assault and battery, breach of the peace, trespass, or destruction of property. Even actions of an undefinable class that present a latent rather than a direct threat to the enforcement of the judgment can often be regulated by enforcing local ordinances dealing with parade permits, public nuisances, and the like.

Courts have perceived, however, that existing state and local statutes are not always adequate to protect the implementation of desegregation decrees. First, criminal proscriptions are limited to relatively narrowly defined conduct, including a specific mental state. It is possible to engage in conduct that is not proscribed by state or local statutes, yet still presents a significant obstruction to peaceful desegregation. ${ }^{27}$ An example of such obstruction is the gathering of small groups of persons along school bus routes. Courts perceive that the mere presence of such groups when school buses are operating under a busing decree presents a potential for violence and intimidates those involved in busing; ${ }^{28}$ yet no state law or municipal ordinance prohibits small groups of parents from walking their children to bus stops.

Another disadvantage of reliance on state and local laws in

Finally, the "city defendants" were ordered to "insure the exclusion from every public school" of all persons except students and enumerated classes of persons who need to enter schools for reasons associated with the normal functioning of the schools. The careful qualifications of these orders suggests that Judge Garrity patterned his orders after the time, place, and manner concerns expressed in Grayned v. City of Rockford, 408 U.S. 104 (1972). For a discussion of Grayned, see Stone, Fora Americana: Speech in Public Places, 1974 SUP. CT. Rev. 233, 250-56. The orders in Morgan v. Kerrigan may be compared with the similar, somewhat less explicitly qualified orders issued in Mims v. Duval County Bd. of Educ., 338 F. Supp. 1208, 1209 (M.D. Fla. 1971), supplemented, 350 F. Supp. 553 (1972).

${ }^{27}$ Other examples of obstruction that are outside the ambit of state and local laws are refusing to send a child to the school assigned under a desegregation decree while keeping the child in the public school system, see Board of Educ. v. York, 429 F.2d 66 (10th Cir. 1970), cert. denied, 401 U.S. 954 (1971), and threatening black parents with economic reprisals if they send their children to "white" schools under a court-ordered freedom of choice plan. See United States v. Farrar, 414 F.2d 936 (5th Cir. 1969).

${ }^{2 \times}$ See note 12 supra. 
effectuating a desegregation decree is that the federal district court must depend on state and local law enforcement institutions to protect an unpopular judgment. Doubts as to the ability and willingness of state and local authorities to protect civil rights adequately were among Congress's motivations in creating and reenacting federal criminal statutes proscribing interference with the exercise of civil rights. ${ }^{29}$

2. Federal Criminal Laws. Sections 241 and 242 of the Federal Criminal Code are companion civil rights statutes which date from the Reconstruction. ${ }^{30}$ Section 241 safeguards a citizen's rights and privileges under the Constitution and laws of the United States against private conspiracies to interfere with the exercise of those rights. ${ }^{31}$ Section 242 proscribes action under color of law that deprives any person of his federal statutory or constitutional rights. ${ }^{32}$ These statutes provided inadequate protection from official and private resistance to the civil rights movement of the 1960s, nearly a century after their enactment. ${ }^{33}$ In response, Congress in 1968 enacted section $245,{ }^{34}$ "by far the most extensive and detailed

23 See United States v. Price, 383 U.S. 787, 807-20 (1965) (legislative history of Enforcement Act of 1870); S. REP. No. 721, 90th Cong., 1st Sess. 4-5 (1967), reprinted in [1968] U.S. Code Cong. \& Ad. News 1837, 1839.

${ }^{30}$ Act of May 31, 1870, § 6, 18 U.S.C. $\S 241$ (1970); Act of Apr. 9, 1886, § 2, 18 U.S.C. $\S$ 242 (1970).

31 18 U.S.C. $\S 241$ (1970) states in relevant part:

If two or more persons conspire to injure, oppress, threaten, or intimidate any citizen in the free exercise or enjoyment of any right or privilege secured to him by the Constitution or laws of the United States, or because of his having so exercised the same . . . They shall be fined . . \$ $\$ 10,000$ or imprisoned . . ten years, or both; and if death results, they shall be subject to imprisonment for any term of years or for life.

3218 U.S.C. $\$ 242(1970)$ states,

Whoever, under color of any law, statute, ordinance, regulation, or custom, willfully subjects any inhabitant of any State, Territory, or District to the deprivation of any rights, privileges, or immunities secured or protected by the Constitution or laws of the United States, . . . shall be fined not more than $\$ 1,000$, or imprisoned not more than one year, or both; and if death results shall be subject to imprisonment for any term of years or for life."

э S. REP. No. 721, supra note 29, at 4-5; 113 CoNG. REC. 22,678-80 (1967) (remarks of Rep. Celler).

34 18 U.S.C. $\S 245$ (1970) was enacted as Title I of the Civil Rights Act of 1968. It now provides, inter alia:

(b) Whoever, whether or not acting under color of law, by force or threat of force willfully injures, intimidates, or interferes with, or attempts to injure, intimidate or interfere with-

(2) any person because of his race, color, religion or national origin and because he is or has been-

(A) enrolling in or attending any public school or public college; . . . ... 
criminal sanction civil rights legislation ever . . . enacted by Congress." 35 Section 245 prohibits any person, whether or not acting under color of law, from interfering "by force or threat of force" with any of the federally protected rights enumerated in the statute, including the right to attend public schools without racially motivated interference. ${ }^{36}$ These statutes are valuable to a desegregation court facing mass resistance to the implementation of its decree. However, several characteristics of these provisions limit their usefulness in combating resistance from an undefinable class. ${ }^{37}$

First, judicial efforts to construe sections 241 and 242 so as to avoid unconstitutional vagueness have narrowed the application of these statutes. The Supreme Court has held that the willful commission of an act that deprives a person of his constitutional rights does not in itself violate sections 241 or $242 .{ }^{38}$ The prosecution must also prove that the defendant acted with a specific intent to "deprive a person of a right which has been made specific either by the express terms of the Constitution or laws of the United States or by decisions interpreting them." ${ }^{39}$ Although the defendant need not have "been thinking in constitutional terms," he must have had a purpose to deprive his victim of a constitutional right. ${ }^{40}$ The vagueness of this specific intent requirement has limited the effectiveness of these sections in punishing violations of civil rights. ${ }^{11}$ Juries hos-

(4) any person because he is or has been, or in order to intimidate such person or any other person or any class of persons from-

(A) participating, without discrimination on account of race, color, religion or national origin, in any of the benefits or activities described . . . or

(B) affording another person or class of persons opportunity or protection to so participate; ... .

shall be fined not more than $\$ 1,000$ or imprisoned not more than one year, or both; and if bodily injury results shall be fined not more than $\$ 10,000$, or imprisoned not more than ten years, or both; and if death results shall be subject to imprisonment for any term of years or for life.

Other activities protected by this statute include voting, participation in any program that is funded by federal funds, and engaging in peaceful protest activities for the purpose of seeking redress for deprivations of constitutional rights or benefits.

33 II National Comm'n on Reform of Federal Criminal Laws, Working Papers 778-79 (1970); see S. REP. No. 721, supra note 29, at 3-4; 113 CoNG. REc. 22,679-80 (1967) (remarks of Rep. Celler).

34 18 U.S.C. $\S \S 245(\mathrm{~b})(2)(\mathrm{A}),(\mathrm{b})(4)(\mathrm{A}) \&(\mathrm{~B})(1970)$.

${ }^{37}$ The other federal criminal statute which has direct relevance to interference with rights under a school desegregation decree, 18 U.S.C. $\$ 1509$ (1970) (obstruction of justice), is discussed in text and notes at notes 129-42 infra.

${ }^{3 *}$ In Screws v. United States, 325 U.S. 91 (1945), the Court incorporated a specific intent requirement into $\S 242$. This requirement was subsequently read into $\S 241$ in United States v. Price, 383 U.S. 787, 796-807 (1966); United States v. Guest, 383 U.S. 745, 753 (1966).

3. Screws v. United States, 325 U.S. 91, 104 (1945).

so Id. at 106.

"For discussion of the practical problems created by the specific intent requirement, 
tile to federal enforcement of civil rights are able to acquit defendants on the basis of the state's failure to prove the existence of such an elusive element of the offense. ${ }^{42}$ This specific intent requirement contributed to a reluctance to use these statutes during periods when the need for federal criminal prosecutions was most pressing. ${ }^{43}$

A second major limit on the use of sections 241 and 242 is that the two statutes have been interpreted not to proscribe all intentional deprivations of constitutional rights. Section 242 punishes only acts done "under color of law," the equivalent of the fourteenth amendment's state action requirement. ${ }^{44}$ In contrast, section 241 is not limited to conduct involving state action. Because the statute can be applied to purely private conduct, courts have construed it to exclude the deprivation of any rights protected by the due process or equal protection clauses of the fourteenth amendment. ${ }^{45}$ Until recently, the Supreme Court refused to apply section 241 when any state action was involved..$^{46}$ Viewing Congress as powerless to prohibit private interference with fourteenth amendment rights, ${ }^{47}$ the Court limited section 241's scope to constitutional and statutory rights existing independently of the fourteenth amendment. ${ }^{48}$

see Clark, A Federal Prosecutor Looks at the Civil Rights Statutes, 47 Colum. L. Rev. 175, 182-84 (1947); Shapiro, Limitations in Prosecuting Civil Rights Violations, 46 CoRnelL L.Q. 532 (1961); Comment, Legislating Civil Rights: The Role of Sections 241 and 242 in the Revised Criminal Code, 63 GEo. L.J. 203, 217-21 (1974).

${ }^{12}$ In Screws v. United States, 325 U.S. 91 (1945), a Georgia sheriff beat a handcuffed black prisoner to death and was convicted under $\S 242$ for depriving a citizen of his life without due process of law. The Supreme Court reversed and remanded; on retrial, Screws was acquitted when the jury was given an instruction containing the specific intent requirement.

${ }^{13}$ See U.S. Comm'n on Civil Rights, Law Enforcement: A Report on Equal Protection IN THE SOUTH 108-09, 118 (1965); authorities cited in note 41 supra.

Another reason for the small number of prosecutions brought under $\S \S 241$ and 242 may have been reluctance on the part of the Department of Justice to intrude into areas of criminal law enforcement normally left to the states. See S. REP. No. 721, supra note 29, at 4. See also B. Marshall, Federalism and Civil Rights 4 (1964), reviewed in Wasserstrom, Book Review, 33 U. Chi. L. REv. 406 (1966). The Screws majority viewed decreased federal enforcement as an advantageous result of the specific intent requirement. Screws v. United States, 325 U.S. 91, 105 (1945). This view has since been substantially eroded. The characterization of civil rights as "affirmative federal rights" has been invoked as a justification for more effective federal criminal legislation protecting civil rights. S. REP. No. 721, supra note 29, at 3-4. In addition, judicial interpretation of the scope of Congress's power to enforce the fourteenth amendment has been significantly broadened. See text at note 52 infra.

"See United States v. Williams, 341 U.S. 70,78 (1951).

t5 See, e.g., United States v. Wheeler, 254 U.S. 281 (1920) (private conspiracy to force persons to leave the state outside scope of $\S 241$ ).

"See United States v. Williams, 341 U.S. 70, 81-82 (1951).

17 See United States v. Harris, 106 U.S. 629 (1882); United States v. Cruikshank, 92 U.S. 542 (1875); Civil Rights Cases, 109 U.S. 3 (1883).

th See, e.g., United States v. Classic, 313 U.S. 299 (1941) (§ 241 protects the right to vote 
Recent Supreme Court decisions have qualified the basis for restricting the scope of these statutes. In United States $v$. Price, ${ }^{49}$ the Supreme Court reversed its previous position and held that sections 241 and 242 are not mutually exclusive: both provisions protect fourteenth amendment rights when the defendant has acted under color of law. ${ }^{50}$ In United States $v$. Guest, ${ }^{51}$ six members of the Court agreed that section 5 of the fourteenth amendment empowered Congress to "enact laws punishing all conspiracies to interfere with the exercise of Fourteenth Amendment rights, whether or not state officers or others acting under the color of law are implicated in the conspiracy."52 However, Justice Stewart, writing for the Court, construed section 241 to "incorporate no more than the Equal Protection Clause itself," 53 thus avoiding the issue of whether section 5 of the fourteenth amendment ${ }^{54}$ empowers Congress to legislate against private conduct. When the conspiracy is directed at the exercise of rights guaranteed by the equal protection clause, as in Guest, ${ }^{55}$ state action must be involved. Justice Stewart found the requisite involvement by interpreting the indictment to allege the cooperation of state officials in the private conspiracy. ${ }^{56}$ Even though a majority of the justices stated that Congress could proscribe purely private violations of fourteenth amendment rights, the Court did not hold that section 241 was such a statute. ${ }^{57}$ Thus, the

in a federal election); In re Quarles, 158 U.S. 532 (1895) (the statute protects the right to inform federal authorities of violations of federal revenue laws); Wilkins v. United States, 376 F.2d 552 (5th Cir.), cert. denied, 389 U.S. 964 (1967) ( $\$ 241$ punishes private person who murdered participant in protest march concerning the right to vote in federal elections). See also United States v. Wheeler, 254 U.S. 281 (1920).

10 383 U.S. 787 (1966).

so Id. at 798; see United States v. Guest, 383 U.S. 745, 753 (1966).

s1 383 U.S. 745 (1966). See generally Cox, Foreword: Constitutional Adjudications and the Promotion of Human Rights, in The Supreme Court, 1965 Term, 80 Harv. L. REv. 91 (1966).

${ }^{52}$ Id. at 782 (Brennan \& Douglas, JJ., Warren, C.J., concurring and dissenting); id. at 761-62 (Clark, Black, \& Fortas, JJ., concurring) (dictum). See generally Note, Federal Power to Regulate Private Discrimination: The Revival of the Enforcement Clauses of the Reconstruction Era Amendments, 74 Colum. L. Rev. 449, 510-17 (1974).

3338 U.S. at 754.

st Section 5 provides, "The Congress shall have power to enforce, by appropriate legislation, the provisions of this article." U.S. CoNST. amend. XIV, $\S 5$.

${ }^{5 s}$ In Guest, a group of whites who had murdered a black man traveling through Georgia were charged with conspiracy, inter alia, to interfere with the victim's right to equal use of state-owned or -operated facilities. 383 U.S. at 747-48.

st 383 U.S. at 756-57. State officials had actively "connived" in the conspiracy by securing false arrests of blacks.

57 Three of the six concurring justices stated that $\$ 241$ encompassed wholly private conspiracies to violate fourteenth amendment rights. Id. at 774-81 (Brennan \& Douglas, JJ., Warren, C.J., concurring and dissenting). The other members of the Guest Court did not 
impact of Guest on section 241 is unclear, ${ }^{58}$ and neither Congress nor the Supreme Court has subsequently construed the statute to encompass private interference with fourteenth amendment rights. ${ }^{59}$

Section 241 would apply to private conspiracies to disrupt school desegregation decrees if the right to attend nonsegregated schools could be derived from a constitutional provision other than the fourteenth amendment, or from a federal statute. Under the thirteenth amendment, Congress has the power to punish racially motivated interference with the exercise of constitutional rights. ${ }^{60}$ However, since Brown, the right to attend schools without regard to race has been considered to flow from the fourteenth amendment. ${ }^{61}$ An alternative approach is to argue that when desegregation is required by a federal court order, the right to attend nonsegregated schools emanates from that order, which is a "law of the United States" within section 241. A similar argument was considered in

express agreement with this view. The majority opinion said, "The statute does not purport to give substantive, as opposed to remedial, implementation to any rights secured by [the equal protection clause]." Id. at 754-55; see id. at 761 (Clark, Black, \& Fortas, JJ., concurring); $i d$. at 762 (Harlan, J., concurring and dissenting).

sx The Court left standing the holding of United States v. Williams, 341 U.S. 70, 73 (1951), that $\S 241$ protects only those rights "arising from the substantive powers of the Federal Government," excluding rights that the Constitution "merely guarantees against abridgement by the States." Id. at 82 .

s) Doubt as to congressional power to proscribe private conduct which interferes with fourteenth amendment rights has divided the circuit courts as to the scope of 18 U.S.C. $\$$ 1985 (3) (1970), the civil analogue of $\S 241$. Compare Westberry v. Gilman Paper Co., 507 F.2d 206, 215 (5th Cir. 1975) (en banc), and Action v. Gannon, 450 F.2d 1227 (8th Cir. 1971) (holding that $\S 1985(3)$ will reach private conduct violating fourteenth amendment rights), with Murphy v. Mount Carmel High School, No. 75-1443 (7th Cir. Oct. 4, 1976), and Bellamy v. Mason's Stores, 508 F.2d 504 (4th Cir. 1974) (holding that $\$ 1985$ (3) does not proscribe private interference with fourteenth amendment rights). In Bellamy, the Fourth Circuit read $\S 1985(3)$ as the Supreme Court's opinion in Guest read $\S 241$ : the statute does not confer any rights in addition to the rights which $\S 1$ of the fourteenth amendment confers of its own force. $508 \mathrm{~F} .2 \mathrm{~d}$ at 507.

Even if $\S 1985(3)$ is properly considered to reach private actions which violate fourteenth amendment rights, it is greatly limited as an effective tool for the enforcement of school desegregation. By its terms, the remedy is limited to actual damages "occasioned by such injury or deprivation." While the court in Action $v$. Gannon did give injunctive relief, such relief is no longer available under the decision of Moor v. County of Alameda, 411 U.S. 693 (1973) (rejecting claim that $\S 1988$ creates an independent federal cause of action for violation of federal civil rights). The Moor Court indicated that an explicit remedial limitation in a Reconstruction statute must be respected. Id. at 702-04, 711 .

${ }^{80}$ See Griffin v. Breckenridge, 403 U.S. 88 (1971); Jones v. Alfred H. Mayer Co., 392 U.S. 409, 438-39 (1968).

"I In Hayes v. United States, 464 F.2d 1252, 1260 (5th Cir. 1972), the court refused to hold that the thirteenth amendment, in addition to the fourteenth amendment, secured the right of black children to attend public schools without regard to race. The Fifth Circuit did, however, find a statutory source of this right, and affirmed a conviction under $\S 241$ for a private conspiracy to blow up school buses. See text and notes at notes 64-69 infra. 
Wilkins $v$. United States. ${ }^{62}$ Although the court found it unnecessary to rule on the merits of this claim, it was properly skeptical as to whether a judicial order could establish a right protected under section 241 that the Constitution or a federal statute had not conferred..$^{63}$

One court has held that section 241 will punish a private conspiracy to interfere with court-ordered busing. In Hayes $v$. United States, ${ }^{64}$ the Fifth Circuit found a statutory basis for the right of black students to attend schools without regard to race. ${ }^{65}$ The court held that Title IV of the Civil Rights Act of $1964^{66}$ secured this right for the purpose of section $241 .{ }^{67}$ However, the court's interpretation of Title IV's application to section 241 will not withstand analysis. The right to attend schools on a nonsegregated basis is implicit in Title IV, but the statute focuses on specific administrative and financial remedies against school officials and has little or no relevance to private resistance to a desegregation decree. There is no indication that Title IV creates any additional rights or duties in the area of school desegregation, ${ }^{68}$ and it is particularly inappropriate to interpret Title IV as affecting the duties of private individuals. ${ }^{69}$

62376 F.2d 552 (5th Cir.), cert. denied, 389 U.S. 964 (1967). In this case, private individuals had conspired to murder participants in a civil rights protest march that was being carried out under a court order.

'3 Id. at 561. The conviction under $\$ 241$ was affirmed on the ground that the marchers were protesting restrictions on voter registration in federal elections, a right secured by the federal constitution.

a 464 F.2d 1252 (5th Cir. 1972). The court relied on Guest in holding that private conspiracies against fourteenth amendment rights are outside $\S 241$. Id. at 1259-60.

is Id. at 1261.

“ 42 U.S.C. $\$ \S 2000 c$ to $2000 c-9$ (1970). The court rested its assertion on $\S 2000 c-2$, which authorizes federal technical and personnel assistance to school boards in drawing up desegregation plans; $\S \S 2000 \mathrm{c}-3,-4$, which concern federally financed training in the problems and techniques of school desegregation; $\S 2000 c-6$, which gives the Attorney General power to institute desegregation suits where complainants are unable to do so; and on a sentence in the legislative history of the Act which affirmed a national policy of assuring the "orderly achievement of desegregation." 464 F.2d at 1261, quoting H. REP. No. 914, 88 Cong., 1st Sess., reprinted in [1964] U.S. CODE CoNG. \& AD. News 2398.

67464 F.2d at 1261 .

"x Indeed, the major concern that courts have expressed in regard to Title IV was that it would limit the equity powers of federal courts. The Act defines desegregation to exclude "the assignment of students to public schools in order to overcome racial imbalance." 42 U.S.C. $\S$ 2000 c(b). The Supreme Court has held that Title IV neither expands nor limits the powers of federal courts to enforce the equal protection clause. Swann v. Charlotte-Mecklenburg Bd. of Educ., 402 U.S. 1, 16-17 (1971). See also McDaniel v. Barresi, 402 U.S. 39, $41-42$ (1971).

" Compare Hayes v. United States, 464 F.2d 1252 (5th Cir. 1972), with United States v. Johnson, 390 U.S. 563 (1968). In Johnson the Supreme Court held that $\S 241$ could reach a private conspiracy to assault blacks for exercising their right to equal use of public accommodations. The statutory codification of this right was found in $\$ 201$ of the Civil Rights Act of 1964,42 U.S.C. $\$ 2000$ a (1970). The statutory source of the protected right is unambiguous. 
The problems of vagueness and narrowness of scope that limited the use of sections 241 and 242 motivated Congress to enact the specific and expansive provisions of section $245 .^{70}$ Unlike section 241 , section 245 encompasses private conduct that interferes with fourteenth amendment rights. ${ }^{71}$ But section 245 is limited to acts of "force or threat of force." The legislative history of the statute indicates that it was intended to "strengthen the capability of the Federal Government to meet the problem of violent interference . . . with the free exercise of civil rights." 22 Thus section 245 cannot reach private, nonviolent conduct ${ }^{73}$ that interferes with the constitutional rights of black school children as defined by a desegregation

"All persons shall be entitled to the full and equal enjoyment of . . . accommodations at any place of public accommodation." This is in sharp contrast to the provisions relied on in Hayes. See Case Comment, Hayes $v$. United States: Private Interference with School Desegregation, 8 HaRv. C.R.-C.L.L. REv. 642, 654-57 (1973).

${ }^{30} \mathrm{~S}$. REP. No. 721, supra note 29 , at 5-6 (1967). For the text of the statute, see note 34 supra. Unlike $\S 241, \S 245$ is not limited to conspiracies. Section 245 does, however, require a showing of specific intent: a defendant must act "because of" racial factors and "because" the victim is engaging in one of the activities protected by the statute. However, Congress was careful to indicate that circumstantial evidence could be the basis of proving intent, $S$. REP. No. 721 , supra note 29 , at 9 , and courts have not found the specific intent requirement a great obstacle to conviction. See, e.g., United States v. Griffin, 525 F.2d 710 (1st Cir. 1975). In this case the defendant, while participating in an antibusing demonstration, assaulted a black man who was not affiliated with the school system either as an employee or as a parent. The court found that the beating nevertheless had a chilling effect on other blacks seeking to exercise their rights to attend nonsegregated schools. The defendant need not have known the federal character or extent of the right of black children to attend nonsegregated schools, so long as he intended to interfere with that right.

"The theory behind the statute is that under $\S 5$ and under the commerce clause, Congress can prohibit racial violence directed at "activities closely related" to the exercise of federally protected activities. "[I]f racial violence directed against activities as closely related to those protected by Federal antidiscrimination legislation is permitted to go unpunished, the exercise of protected activities will be deterred." S. REP. No. 721, supra note 29, at 6-7. Congress considered the agreement of the six Justices in Guest to have ended the doubts regarding legislation prohibiting private actions which violate fourteenth amendment rights. Id. at 7.

72114 Cong. Rec. 318-19 (remarks of Sen. Hart); id. at 535 (1968) (remarks of Sen. Javits); 113 ConG. REc. 22757, 22678 (remarks of Rep. Celler); id. at 22685 (remarks of Rep. McClory) (1967); H. Rep. No. 473, 90th Cong., 1st Sess. 3-4 (1967). See also II National Comm'n on Reform of Federal Criminal Laws, Working Papers 769 (1970) (noting that school desegregation is primarily approached through "noncriminal sanction techniques" unless and until interference rises to the level of violence or fraud).

${ }^{73}$ The Supreme Court has construed $\$ 245$ to prohibit only violent interferences with the exercise of the specified rights. Johnson v. Mississippi, 421 U.S. 213, at 224 (1976) (orderly arrest pursuant to state law enforcement is not "force or threat of force"). A vigorous dissent by Justice Marshall argued that the statute had "broad remedial purposes and effects." Id. at 232. The dissent insisted on construing "force or threat of force" in light of these "broad remedial purposes," concluding that the process of arrest and prosecution was the method by which state officials could "most plausibly exert force or the threat of force." Id. at 238 . See also New York v. Horelick, 424 F.2d 697, 703 (2d Cir.), cert. denied, 398 U.S. 939 (1970). 
decree. Section 241 is not restricted to acts of force, ${ }^{74}$ but under present law, private interference with fourteenth amendment rights, including the right to attend nonsegregated schools, is not within the ambit of section $241 .{ }^{75}$ Wholly private acts of nonviolent interference with the implementation of school desegregation decrees are therefore not within the scope of these federal criminal statutes. ${ }^{76}$

Procedural requirements further curtail the usefulness of both state and federal criminal statutes. Constitutional objections to the statutes can be raised, and a jury trial is necessary, before criminal sanctions can be imposed. In contrast, the procedure in prosecutions for criminal contempt when a court's order has been violated are relatively summary. ${ }^{77}$ Finally, a court cannot initiate a criminal prosecution. ${ }^{78}$ All of these factors contribute to the courts' perception of their powerlessness in the face of resistance to desegregation judgments. ${ }^{79}$ Seeking a method of vindicating their own authority courts have sought remedies that are more responsive to their institutional vulnerabilities and needs.

\section{B. Injunctive Orders}

Injunctive orders offer several major advantages over criminal sanctions as a means of enforcing school desegregation judgments. First, injunctions may be tailored to the kinds of conduct that the

"See, e.g., Anderson v. United States, 417 U.S. 211 (1974) (officials who stuffed ballot box were convicted for conspiracy to interfere with right to vote in federal election).

${ }^{75}$ But see Rosecrans v. United States, 378 F.2d 561 (5th Cir. 1967), where violent interference with a school desegregation decree was held to violate $\S 241$. Rosecrans had engaged in several bombings, including the bombing of a private home. There was no showing of state action. On these facts, the defendant could clearly have been indicted for violating $\S 245$. But the case is at best a doubtful application of $\$ 241$.

" For example, private persons who threaten economic reprisals for participation in a desegregation decree, or enter school grounds and cause minor disruptions, or make nonthreatening but nonetheless intimidating speeches, with the intent to disrupt the orderly implementation of desegregation, have not violated $\S \S 241,242$, or 245 .

7 In federal courts, a jury trial is available in criminal contempt cases where the sentence allowed or imposed is more than six months. Cheff v. Schnackenberg, 384 U.S. 373, 380 (1966). In state courts, jury trial is required for contempt where the offense is "serious." Bloom v. Illinois, 391 U.S. 194 (1968). See generally Dobbs, Contempt of Court: A Survey, 56 CoRnell L. REv. 183, at 230-34 (1971).

73 See Peek v. Mitchell, 419 F.2d 575 (6th Cir. 1970) (Attorney General cannot be compelled to prosecute violations of civil rights statutes); United States v. Cox. 342 F.2d 167 (5th Cir.) (United States Attorney cannot be so compelled), cert. denied, 381 U.S. 935 (1965).

"The State and local governments possess all police powers necessary to enforce violations of the criminal laws of this State and so insure the safety and welfare . . . . At the same time, this Court is under the duty to enforce its orders and to preserve the integrity and effectiveness thereof." Stell v. Board of Educ., No. 1316 (S.D. Ga., March 16, 1972) (TRO prohibiting "all persons" from "in anywise interfering" with the desegregation decree). 
court perceives to present a threat to enforcement, even if such conduct violates no positive law. Second, violations of an injunction can be punished in summary contempt proceedings, ${ }^{80}$ in which the collateral bar rule $e^{81}$ prevents alleged contemnors from raising substantive objections to the validity of the injunction. Third, through the contempt power, the court that issued the injunction is empowered to sanction violations of its authority. ${ }^{82}$ The most important limits on the effectiveness of injunctive orders as a method of enforcing judgments are the procedural requirements for issuance rather than the nature of the conduct that may be proscribed ${ }^{83}$ or the procedures for enforcing orders that have been violated.

The issuance and effect of injunctions and temporary restraining orders (TROs) in the federal courts are governed by rule 65 of the Federal Rules of Civil Procedure. ${ }^{84}$ The dominant purpose of the

${ }^{80}$ The procedures for criminal contempt prosecutions are set out in rule $42(\mathrm{~b})$ of the Federal Rules of Criminal Procedure.

81 The collateral bar rule provides that one charged with violating an injunction cannot raise the erroneousness or unconstitutionality of the injunction as a defense to contempt. The only available defenses are that the injunction was void for lack of jurisdiction over the person or over the subject matter, the contemnor had no notice of the injunction, did not violate it, or was unable to comply. See generally Dobbs, Contempt of Court: A Survey, 56 Cornelu L. REv. 183, 261-67 (1971). There is no bar to the assertion of defenses that statutes or ordinances are invalid in proceedings against persons accused of violating them. Nor does failure to obey a police order bar defenses based on its invalidity. Wright v. Georgia, 373 U.S. 284 (1963). The asserted difference between injunctions on the one hand, and statutes, ordinances, and police orders on the other, is the need to preserve the respect and dignity of the court issuing the injunction, and to prevent "litigation on the streets." Compare Walker v. City of Birmingham, 388 U.S. 307, 320 (1967) (injunction), with Shuttlesworth v. City of Birmingham, 394 U.S. 147 (1969) (ordinance).

To apply the collateral bar rule against nonparty contemnors precludes any opportunity for such contemnors to litigate the substantive validity of the injunction. See, e.g., Reich v. United States, 239 F.2d 134, 137-38 (1st Cir. 1956), cert. denied, 352 U.S. 1004 (1957). The application of the collateral bar rule has been extensively criticized. See, e.g., Cox, The Void Order and the Duty to Obey, 16 U. CHI. L. REv. 86 (1948); Comment, Defiance of Unlawful Authority, 83 HARv. L. Rev. 626, 629-38 (1969).

82 [T] he power of a court to make an order carries with it the equal power to punish for a disobedience of that order, and the inquiry as to the question of disobedience has been from time immemorial, the special function of the court. And this is no technical rule. In order that a court may compel obedience to its orders it must have the right to inquire whether there has been any disobedience thereof. To submit the question of disobedience to another tribunal . . . would operate to deprive the proceeding of half its efficiency.

In re Debs, 158 U.S. 564, $594-95$ (1895). A federal court is empowered to punish "at its discretion, such contempt of its authority, and none other, as- . . (3) Disobedience or resistance to its lawful writ, process, order, rule, decree, or command." 18 U.S.C. $\S 401$ (3) (1970). For the full text of the statute, see note 168 infra.

${ }^{83}$ When conduct protected by the first amendment is involved, the constitutional protection may be an equally important limit on judicial authority, See note 11 supra.

${ }^{84}$ For the relevant parts of rule 65 , see notes $97 \& 102$ infra. 
requirements imposed by rule 65 is to limit the exercise of discretion by federal courts issuing injunctions or TROs. ${ }^{85}$ The legal ancestor of rule 65 , the Clayton Act ${ }^{86}$ sought to limit what were considered endemic abuses in the issuance of injunctions. ${ }^{87}$

The Supreme Court has taken an expansive view of the kinds of judicial orders that are subject to rule 65. In Local 1291, International Longshoremen's Association v. Philadelphia Marine Trade Association, ${ }^{88}$ the Court found that even though a district court order enforcing an arbitrator's award might not be an "injunction" within the meaning of the Norris-LaGuardia Act, ${ }^{89}$ it was still an "equitable decree compelling obedience" and therefore an "order granting an injunction" for the purpose of rule 65(d). ${ }^{90}$ Similarly, court orders "enforcing" prior orders of the National Labor Relations Board are within the ambit of rule $65 .{ }^{.1}$ The same reasoning should bring orders enforcing outstanding judgments of federal district courts within rule 65 . Orders enforcing judgments are injunctive in effect; their use and scope should therefore be governed by the law of injunctions.92

The notice and hearing requirements of rule 65 furnish an important restriction on the issuance of injunctive relief. A court can

ss 7 Moore's Federal Practice | 65.02[1], at 65.17 (2d ed. 1975) (rule 65 "reflects the long established policy of strict control of the injunctive process-a policy generally reflected in the careful exercise of the power to issue the injunction, preliminary or final, in any of its several forms").

ss Sections 17 and 19 of the Clayton Act, Act of Oct. 15, 1914, Ch. $323 \S \S 17,19,38$ Stat. 737,738 , were enacted as part of the Judiciary Code of 1940,28 U.S.C. $\$ \S 381,383$. These sections were repealed in 1948, having been replaced by rules 65(b) and 65(d). 7 MOORE's Federal Practice If 65.01[4], -01[10], at 65-7 n.1 and 65-12 n.6 (2d ed. 1975).

"7 Section 19 of the Clayton Act, from which the rule was taken, was designed to cure inter alia "the issuance of injunctions without parties." See 48 CoNG. REc. 6436, 62d Cong., 2d Sess. (1912) (remarks of Rep. Davis). In the House report, Rep. Clayton described the purpose of the provisions: "The too ready issuance of injunctions or the issuance without proper precautions or safeguards has been called to the attention of Congress session after session. . . The bill . . . seeks to remedy the evils complained of . . . " H.R. REP. No. 612, 62d Cong., 2d Sess. 18 (1912). See also F. Frankpurter \& N. Greene, The Labor InJUNCTION 185 (1930) (stating that the relevant sections of the Clayton Act were intended to correct the issuance of injunctions without notice, detail, or parties).

389 U.S. 64 (1967).

* 29 U.S.C. $\S 101$ (1970).

- 389 U.S. at 75.

" Golden State Bottling Co. v. NLRB, 414 U.S. 168, 177 (1973); Regal Knitwear v. NLRB, 324 U.S. 9, 13-15 (1945).

1 See Rendleman, Obligors to Injunctions, supra note 8, at 876, citing F. MaITLAND, EQuITY 9 (2d ed. 1936) ("An injunction is a court order requiring a person to do something or forbidding a person from doing something"). See also 2 STORY'S EQUTTY JURISPRUDENCE $\$ 861$ (1st ed. 1836) ("A Writ of Injunction may be described to be a judicial process, whereby a party is required to do a particular thing, or to refrain from doing a particular thing, according to the exigency of the writ"). 
issue preliminary and permanent injunctions only after providing notice and an adversary hearing to the person sought to be enjoined. ${ }^{93}$ These procedural requirements assume the existence of adverse parties..$^{94}$ Such an assumption may not be warranted when orders are issued against a community to enforce a desegregation judgment. When the plaintiff in a desegregation suit petitions for such an order, the "adverse parties" are the plaintiff class and the community at large. Unless there is an identifiable representative of the community, notice and a hearing are impossible.$^{95}$

${ }^{93}$ FED. R. Civ. P. 65(a)(1). For the importance of an adversary hearing prior to the issuance of an injunctive order under rule 65, see Sims v. Greene, 161 F.2d 87 (3d Cir. 1947).

94 See FED. R. Crv. P. 65(a)(1), (b).

${ }^{95}$ Even if a representative of the community's interests could be identified and given notice and a hearing, the "class" of persons who are members of the community would not be bound to orders directed to the representative unless their relationship to the representative is within rule 65(d) (as agent or as one in active concert). See United States v. American Optical Co., 97 F. Supp. 66 (N.D. Ill. 1951). In this case, the United States brought an antitrust suit against the American Optical Company and 22 named doctors, representing a class of approximately 2,000 doctors charged with having received certain rebates in violation of the Sherman Act. The court explained its injunction against a defendant class. "Not only are the defendants alleged to be members of a class, but they are alleged to have participated in active concert with the corporate defendants and other members of the class . . . "Id. at 70 . The court emphasized that this defendant class injunction was consistent with rule 65(d) and conformed to common law notions of in personam jurisdiction. Id. at 69-70.

But see Environmental Defense Fund v. Environmental Protection Agency, 485 F.2d 780 (D.C. Cir.), aff'd by an equally divided court sub nom. Fri v. Sierra Club, 412 U.S. 541 (1973), where a TRO against further proceedings in a suit pending in the Northern District of Mississippi had been issued against the parties to that suit. Subsequent to the issuance of that restraining order, the district court in Mississippi allowed intervention by representatives of a "class of farmers, all residents of Mississippi, producing cotton." The circuit court responded with an order that amended the TRO to include the individual intervenors and the class they represented. The circuit court noted that rule 65(d) provides that "nonparties in general" are not bound to TROs, but insisted that there was "an identity of interest between the class intervenors . . . and the parties to our review proceedings." 485 F.2d at 784 n.2. There is no indication that the representatives of the class intervenors were served with notice before being included as parties to the TRO which had already been issued. Thus, the failure to comply with rule 65(b)'s notice requirements explains the circuit court's attempt to establish an identity of interest between the class intervenors and the original parties to the TRO. To support its argument, the court invoked the "inherent power to protect [a court's] jurisdiction from being obstructed by the actions of non-parties properly on notice . . .." Id., citing United States v. Hall, 472 F.2d 261 (5th Cir. 1972), discussed in text and notes at notes $152-90$ infra.

If the circuit court had issued a separate TRO to the class intervenors, notice and hearing for the representatives would have been possible. The class had already been defined, and the named intervenors had established themselves as representatives. But even though this class was appropriate for the purposes of intervention, it is doubtful that membership in such a class could bind a person to the circuit court's TRO. Rule 65(d) does not mention a category of bound nonparties equivalent to the "identity of interest" claimed by the circuit court. The members of the intervenor class do not appear to be in an agency relation to the individual intervenors or parties to the previous TRO, nor are they likely to be in active concert with such persons. Thus, even if notice and a hearing are possible for representatives of a valid 
Another, and perhaps the most important, limit on the use of injunctions and TROs is the "scope" limitation of rule $65 .{ }^{96} \mathrm{In}$ rule 65(d), Congress declared that only parties and an exclusive enumeration of persons related to the parties are subject to the jurisdiction of the enjoining court. ${ }^{97}$ The rule's enumeration of the class of persons who can be bound reflects the common law notion of in personam jurisdiction ${ }^{98}$ as a fundamental limit on the power to compel obedience to a court order..$^{99}$ The exceptions to this scope limitation

class, the members of the class itself will not be bound to an order directed to the class as a defendant merely by virtue of membership in the class.

Compare the Supreme Court's recent indication that attenuated notions of privity similar to the "identity of interest" invoked in Environmental Defense Fund do not suffice to bind nonparties to injunctions, in Zenith Corp. v. Hazeltine, 395 U.S. 100, 109-10 (1969) (injunction against subsidiary not binding on parent corporation). The Supreme Court cited Hans. berry v. Lee, 311 U.S. 32, 40-41 (1940), and Pennoyer v. Neff, 95 U.S. 714 (1878), to support the proposition that "[i]t is elementary that one is not bound by a judgment in personam [unless] . . . he is designated as a party . . . "395 U.S. at 110.

For a discussion of the interaction of rule 23 (class actions) and rule 65, see 0 . Fiss, INJUNCTIONS 676 (1972).

" "Scope" describes the jurisdictional limits on a court's injunctive power. See Regal Knitwear Co. v. NLRB, 324 U.S. 9 (1945); 7 Moore's Federal Practice 16 65.13, at 65-109117 (2d ed. 1975). See generally O. Fiss, Inנunctions 620.45 (1972); Developments in the Law-Injunctions, 78 HaRv. L. REv. 994, 1028-31 (1965).

"Rule 65(d) states:

Every order granting an injunction and every restraining order shall set forth the reasons for its issuance; shall be specific in terms; shall describe in reasonable detail, and not by reference to the complaint or other document, the act or acts sought to be restrained; and is binding only upon the parties to the action, their officers, agents, servants, employees, and attorneys, and upon those persons in active concert or participation with them who receive actual notice of the order by personal service or otherwise.

" As a matter of due process, a person is ordinarily not bound by an in personam proceeding of which he had no notice and no opportunity to be heard. $C f$. Pennoyer v. Neff, 95 U.S. 714 (1877) (personal judgment issued ex parte in state court against nonresident without personal service of process offends due process).

" An examination of the evolution of rule 65(d) reflects the tension between effective use of injunctions and the traditional requirement of in personam jurisdiction. This tension was evident in the Supreme Court's language in two cases in the 1890s. In Scott v. Donald, 165 U.S. 107 (1897), the Court emphasized traditional jurisdictional requirements. "We do not think it comports with well-settled principles of equity procedure to include [those not namedl in an injunction in a suit in which they were not heard or represented . . . ." Id. at 117. In re Lennon, 166 U.S. 548 (1897), on the other hand, contains language so broad as to emasculate any jurisdictional limit. "To render a person amenable to an injunction it is neither necessary that he should have been a party to the suit in which the injunction was issued, nor to have been actually served with a copy of it, so long as he appears to have had actual notice." Id. at 554 .

In 1930, this apparent inconsistency was acknowledged in Alemite Mfg. Corp. v. Staff, 42 F.2d 832 (2d Cir. 1930). Judge Hand, distinguishing Lennon, stated: "[N]o court can make a decree which will bind any one but a party; . . . it cannot lawfully enjoin the world at large, no matter how broadly it words its decree. If it assumes to do so, the decree is pro tanto brutum fulmen, and the persons enjoined are free to ignore it." Id. at 832 . Hand's position was adopted by the Supreme Court in Chase Nat'l Bank v. City of Norwalk, 291 U.S. 
fall into two major categories. The first is a broad agency concept that includes nonparties who could be said to be acting in the place of the restrained party. In order to prevent the facile circumvention of the injunction by persons acting on behalf of the party, those in certain legal relationships to the named party will also be bound..$^{100}$ The notion of acting on behalf of the bound party carries over into the second major category, persons aiding and abetting the restrained party to disobey an injunction. Instead of emphasizing the preexisting legal relationship, this category stresses the element of conspiracy; persons in "active concert" are sufficiently related to parties to justify binding them without naming them as addressees or acquiring jurisdiction over them by personal service. ${ }^{101}$

A temporary restraining order can issue without prior notice and hearing. ${ }^{102}$ TROs thus allow a court to enjoy the advantages of

431, 436-37 (1934), and reaffirmed in Regal Knitwear Co. v. NLRB, 324 U.S. 9, 13-14 (1945), and Zenith Radio Corp. v. Hazeltine Research, Inc., 395 U.S. 100 (1969). See generally Rendleman, supra note 8, at 901-11, In Nebraska Press Ass'n v. Stuart, 96 S. Ct. 2791, 2806 (1976), the Supreme Court found a silence order concerning news coverage of a criminal trial offensive to the first amendment. The Court noted that the need for in personam jurisdiction is an additional obstacle to silence orders that apply to publication outside a court's territorial jurisdiction.

${ }^{100}$ For a summary of the agency notion which binds unnamed persons to an injunctive order, see text and authorities cited in Rendleman, supra note 8, at 892-99. For an expansive view of the agency/privity exception, see Golden State Bottling Co. v. NLRB, 414 U.S. 168, 180 (1973), holding that bona fide purchasers of a business with unremedied unfair labor practices, who had knowledge of such unfair practices, could be considered in privity with the enjoined precedessor within the meaning of rule 65(d). The Court found that the "tie between the offending employer and bona fide purchaser . . . establishes the requisite relationship of dependence." Id. The Court relied in part on United States v. Hall, 472 F.2d 261 (5th Cir. 1972), to support its liberal reading of the agency exception. See discussion in text and notes at notes $152-190$ infra.

${ }^{101}$ See, e.g., Regal Knitwear Co. v. NLRB, 324 U.S. 9, 14 (1945); Chase Nat'l Bank v. City of Norwalk, 291 U.S. 431, 436-37 (1934); Gay Students Organization v. Bonner, 509 F.2d 652, 657 (1st Cir. 1974); Heyman v. Kline, 444 F.2d 65 (2d Cir. 1971); Bullock v. United States, 265 F.2d 683 (6th Cir.), cert. denied, 360 U.S. 909 (1959); Alemite Mfg. Corp. v. Staff, $42 \mathrm{~F} .2 \mathrm{~d} 832$ (2d Cir. 1930). A recent case which rejects an application of "active concert" as a means of binding a successor in interest is Herrlein v. Kanakis, 526 F.2d 252 (7th Cir. 1975), discussed at note 190 infra.

For critical discussions of the traditional equity categories of persons "sufficiently related" to parties to justify binding them, see Rendleman, supra note 8, at 877-82; Note, Binding Nonparties to Injunction Decrees, 49 MiNN. L. REv. 719 (1965).

${ }^{102}$ Rule 65(b) (1970) states:

A temporary restraining order may be granted without written or oral notice to the adverse party or his attorney only if (1) it clearly appears from specific facts shown by affidavit or by the verified complaint that immediate and irreparable injury, loss, or damage will result to the applicant before the adverse party or his attorney can be heard in opposition, and (2) the applicant's attorney certifies to the court in writing the efforts, if any, which have been made to give the notice and the reasons supporting his claim that notice should not be required. 
injunctive orders ${ }^{103}$ while avoiding one of the major procedural limits on the expeditious issuance of such orders. However, because "our entire jurisprudence runs counter to the notion of court action taken before reasonable notice and an opportunity to be heard has been granted both sides of a dispute," 104 rule 65 imposes severe restrictions on the issuance of TROs. One such restriction is that the issuance of ex parte orders is permitted only in situations where plaintiffs cannot be protected if an order is delayed until an adversary hearing is held. ${ }^{105}$ Another restriction is embodied in the 1966 amendment to rule $65(\mathrm{~b}),{ }^{106}$ which requires the applicant's attorney to certify any attempts to give notice to the adverse party and the reasons why notice should not be required in the particular case. ${ }^{107}$ Still another statutory manifestation of the importance of prior notice is the ten-day limit on the duration of all TROs; after ten days a hearing must be held to determine whether the order should be made a preliminary or permanent injunction. ${ }^{108}$

The absence of notice and hearing requirements for the issu-

The remainder of rule $65(\mathrm{~b})$ requires that the order state why it was granted without notice and why the injury threatened was irreparable, and sets a ten-day limit on ex parte TROs, with a ten-day extension period permitted with the consent of the party being enjoined or on a showing of good cause. Provision is made for an adverse party to appear and move for dissolution or modification two days after notifying to the party who obtained the TRO.

105 Objections to the application of the collateral bar rule to ex parte orders have emphasized the quasi-legislative character of such orders. See text and notes at notes $170 \& 187$ infra. The legislative quality of a judicial rule was recognized as a basis for relaxing the collateral bar rule in In re Oliver, 452 F.2d 111 (7th Cir. 1971).

104 Granny Goose Foods v. Brotherhood of Teamsters Local 70, 415 U.S. 423, 439 (1974). The Court continued, "Ex parte temporary restraining orders are no doubt necessary in certain circumstances . . . , but under federal law they should be restricted to serving their underlying purpose of preserving the status quo and preventing irreparable harm just so long as is necessary to hold a hearing, and no longer." Id. (citation omitted).

${ }_{106}$ FEd. R. Crv. P. 65(b).

106 FED. R. Civ. P. 65(b)(2).

I0f The 1966 Advisory Committee's Note to rule 65(b) explains this requirement:

In view of the possibly drastic consequences of a temporary restraining order, the opposition should be heard, if feasible, before the order is granted. . . . [W] hen time does not permit of formal notice . . . some expedient, such as telephonic notice to the attorney for the adverse party, [should] be resorted to if this can reasonably be done.

39 F.R.D. 69, 124-25 (1966). The courts have been scrupulous in requiring notice absent a convincing showing of unreasonable difficulty and subsequent danger to the plaintiff's rights. See, e.g., Emery Air Freight Corp. v. Local 295, Int'l Bhd. of Teamsters, 449 F.2d 586, 591 (2d Cir. 1971), cert. denied, 405 U.S. 1066 (1972). The requirement of reasonable efforts to provide notice was given a constitutional dimension in Carroll v. President \& Comm'rs of Princess Anne County, 393 U.S. 175 (1968), where a county court issued an ex parte TRO that operated as a prior restraint on speech. Notice when possible, but not the specific requirements of rule $65(\mathrm{~b})$, was held to be constitutionally required in the first amendment context. See texts and notes at notes 200-11 infra.

tax FED. R. Crv. P. 65(b)(2). 
ance of TROs makes the limits on the scope of such orders crucial. Like injunctions, TROs are binding only "upon the parties to the action, their officers, agents, servants, employees, and attorneys, and upon those persons in active concert or participation with them who receive actual notice of the order by personal service or otherwise." ${ }^{109}$ Ex parte TROs that seek to bind a group of persons by naming them individually ${ }^{110}$ must be distinguished from those that seek to bind a group by describing the characteristics of that class of persons. When a described class of persons can be translated easily into a list of names, the difference between party by enumeration and party by description is largely formal and insubstantial. ${ }^{111}$ But when the group sought to be reached consists of unidentified persons who are not related to an identifiable party who could adequately represent them, the group constitutes an undefinable class. ${ }^{12}$ In this situation, allowing persons "described" in an order to be equated with "parties" is to claim a dramatic expansion of equitable power. ${ }^{113}$

Community resistance to the enforcement of school desegregation presents the problem of judicial control of an undefinable class. However, the scope limitations of injunctions and ex parte TROs do not preclude the effective use of injunctive orders to control community resistance in all situations. A court can wait to identify individuals, especially leaders of various groups, who are resisting the enforcement of the desegregation judgment before issuing injunctive orders addressed to such individuals. ${ }^{114}$ If a court expects endemic community resistance for a substantial period of time,

${ }^{109}$ Fed. R. Civ. P. 65(d).

10 In Walker v. Birmingham, 388 U.S. 307 (1967), the court named 139 individuals and 2 organizations as addressees of the restraining order. Thus, the class of demonstrators was bound by name rather than description.

i' For a defendant class that could be named rather than described, see Hadnott v. Amos, 295 F. Supp. 1003 (M.D. Ala. 1968) (per curiam), rev'd on other grounds, 394 U.S. 358, 399 (1969) (probate judges of all counties in Alabama); United States v. American Optical Co., 97 F. Supp. 66 (N.D. Ill. 1451) (approximately 2,000 doctors engaged in rebate scheme). In American Optical, the defendant class was in "active concert" within the meaning of rule 65(d). See note 95 supra.

112 See, e.g., Hall v. United States, 472 F.2d 261, 266 (5th Cir. 1972). For other examples of orders which purport to bind an undefinable class in the desegregation context, see note 21 supra.

${ }^{113}$ See generally Note, Binding Nonparties to Injunction Decrees, 49 MinN. L. REv. 719 (1965); Note, The Range of Federal Injunctions, 6 Utar L. Rev. 363 (1959); Note, Contempt by Strangers to a Federal Court Decree, 43 VA. L. Rev. 1294 (1957); Note, Contempt Proceedings Against Persons Not Named in an Injunction, 46 HARV. L. REv. 1311 (1933).

I1 See, e.g., Augustus v. School Bd., 507 F.2d 152 (5th Cir. 1975); Faubus v. United States, 254 F.2d 797, 806-07 (8th Cir. 1958); Kasper v. Brittain, 245 F.2d 92 (6th Cir.), cert. denied, 355 U.S. 834 (1957). 
waiting for resisters to identify themselves by acts of obstruction can be an effective method of coping with problems posed by an undefinable class. ${ }^{115}$ As more resisters are identified and enjoined, the undefinable class is gradually reduced by the creation of defined classes of enjoined parties and persons related to parties within the meaning of rule $65(\mathrm{~d}){ }^{116}$ Coverage will never be as summary or as broad as under orders purporting to bind "other persons acting independently . . . having notice,"117 but the most persistent sources of resistance and incitement to resistance will eventually become subject to the authority of the court.

Allowing those interfering with the court's decree to identify themselves by taking a "free bite" before an injunction naming them is issued may have serious drawbacks in some situations. If community resistance is very unorganized, or if organization is very diffuse, then the process of narrowing the classes of persons in the undefinable class by the issuance of new injunctions designed to reach groups of persons in active concert with the leaders-addressees may be prohibitively slow and onerous for the court's needs and capacities. ${ }^{118}$ In addition, the period immediately following the im-

IIs See, e.g., Board of Educ. v. York, 429 F.2d 66 (10th Cir. 1970), cert. denied, 401 U.S. 954 (1971) (injunction against parents who refused to send their child to his newly assigned school pursuant to a desegregation decree); Rendleman, supra note 8, at 909-10. But cf. 0 . Fiss, InJunctions 629 (1972) (questioning the "functional significance" of allowing resisters a "second chance"). Professor Fiss speculates "as to whether the obstruction-of-justice concept has emerged in a new form," and expresses doubt that the "second chance" is "rooted in any deep sense of fairness." Id.

116 See, e.g., Kasper v. Brittain, 245 F.2d 92 (6th Cir.), cert. denied, 355 U.S. 834 (1957), where the district court issued a TRO naming Kasper and ordering him "and others" to refrain from "interfering with the carrying out" of the school desegregation judgment, "either by words, acts, or otherwise." Id. at 94. Kasper violated the order on the day he received notice of its issuance. In an adversary hearing held after Kasper's violation, the appellate court held the restraining order "to have been properly issued and . . . the evidence justified its continuance as a preliminary injunction." Id. The injunction was made permanent eight days after the TRO was issued. Since the leader of those interfering with the desegregation decree could be identified, he could be personally restrained, then enjoined, from such resistance. Persons who, with knowledge of the order, acted in concert with him were also bound. See Bullock v. United States, 265 F.2d 683 (6th Cir.), cert. denied, 360 U.S. 909 (1959), where the defendant was convicted of contempt for violating the restraining order issued in Kasper $v$. Brittain, despite the fact that he had not been named as a party to the TRO or to the preliminary and permanent injunctions. Instead, Bullock was found to have acted in "active concert" with Kasper, a party defendant. Id. at 687,692 ; see note 95 supra.

11 United States v. Hall, 472 F.2d 261, 263 (5th Cir. 1972).

I1x See Brief for Respondents at 18, United States v. Hall, 472 F.2d 261 (5th Cir. 1972) ("In a normative and practical vein, district courts in school desegregation cases involving the hybrid and volatile type of situation described herein should not be required to issue a multitude of Orders or temporary restraining orders ad infinitum against a class of people who are after the fact violators or otherwise undefinable"). 
plementation of the desegregation decree, when injunctions are least effective in terms of scope of coverage, may present the gravest threat to civil order and the enforcement of the judgment.

\section{The All Writs Act}

One statutory source of authority relied on by district courts to issue injunctive orders enforcing their judgments is the All Writs Act, ${ }^{119}$ which authorizes courts to issue "all writs necessary or appropriate in aid of their . . . jurisdictions" that are "agreeable to the usages and principles of law." 120 This statute empowers courts to enjoin actions that improperly impede or defeat the exercise of their jurisdiction. The Act serves in part as a codification of the inherent power of a court to enforce and protect its judgments and decrees. ${ }^{121}$

The All Writs Act does not confer original jurisdiction on a district court. It can be invoked only in "aid" of jurisdiction already acquired. ${ }^{122}$ Although power under the Act is to be broadly construed once jurisdiction is established, ${ }^{123}$ the statute does not release a court from compliance with fundamental procedural requirements. ${ }^{124}$ When a court issues an injunctive order pursuant to the All Writs Act, it must have previously acquired jurisdiction over the injunction defendant or fully complied with the procedures for issuance of ex parte temporary restraints. ${ }^{125}$

For congressional recognition of the inadequacy of such injunctive orders, see text and notes at notes 130-34 infra.

11928 U.S.C. $\S 1651$ (1970).

120 For the history of the All Writs Act, see 9 Moore's Federal Practice $\{110.26$, at 277 78 (2d ed. 1975); Bell, The Federal Appellate Courts and the All Writs Act, 23 Sw. L.J. 858, 859-60 (1969). The Act confers the general common law writ power on the federal courts.

121 Mississippi Valley Barge Line Co. v. United States, 273 F. Supp. 1, 6 (E.D. Mo. 1967), aff'd sub nom. Osbourne v. Mississippi Valley Barge Line Co., 389 U.S. 579 (1968) (per curiam); 9 Moore's Federal Practice II 110.29, at 316-18 (2d ed. 1975).

122 See 7B Moore's Federal Practice $\S 1651$, at JC-803 (2d ed. 1975).

${ }^{123}$ E.g., Hamilton v. Nakai, 453 F.2d 152, 157 (9th Cir. 1971), cert. denied, 406 U.S. 945 (1972).

${ }^{124}$ In Ben David v. Travisono, 495 F.2d 562 (1st Cir. 1974), the district court had issued a preliminary injunction restraining prison officials from "brutalizing" inmates in retaliation for their participation in a civil rights suit over which the court had jurisdiction. The court did not give the reasons for the injunction or state with particularity the acts enjoined as required by rule $65(\mathrm{~d})$, nor did it consider the usual criteria governing the issuance of injunctive orders (e.g., probability of actual harm). The district court relied on $\S 1651$ to justify these relaxed procedures. On appeal, it was held that the district court had "confused its substantive power to protect [its jurisdiction] with the procedural requirements governing the use of such power," and the order was modified to comply with rule 65 (d). $495 \mathrm{~F} .2 \mathrm{~d}$ at 563.

125 In Commercial Security Bank v. Walker Bank \& Trust Co., 456 F.2d 1352, 1355 (10th Cir. 1972), the circuit court held that the lower court had no jurisdiction to enter an ex parte 
When a court retains jurisdiction over a school desegregation decree, ${ }^{126}$ it conclusively establishes the independent basis of subject matter jurisdiction necessary for the issuance of subsequent orders under the All Writs Act. ${ }^{127}$ But unless subsequent orders are issued to persons already parties to the underlying suit, ${ }^{128}$ neither the All Writs Act nor the existence of retained jurisdiction dispenses with the necessity of achieving personal jurisdiction over the addressees of the orders and complying with rule 65 . Orders directed to an undefinable class of persons, who have not received notice or an opportunity for a hearing prior to the issuance of an order, cannot be justified by the All Writs Act whether or not combined with retained jurisdiction.

\section{Obstruction of Justice}

As part of the 1960 Civil Rights Act, Congress passed a new

injunction under $\S 1651$ against the United States when the government had not been served with process and was not before the court, stating that injunctions issued under $\$ 1651$ must comply with the limits imposed by rule 65 . See also E. F. Hutton \& Co. v. Brown, 305 F. Supp. 371, 379 (S.D. Tex. 1969). But cf. Mississippi Valley Barge Line Co. v. United States, 273 F. Supp. 1 (E.D. Mo. 1967), aff'd sub nom. Osbourne v. Mississippi Valley Barge Line Co., 389 U.S. 579 (1968) (per curiam). Language in Mississippi Valley Barge Line suggests that a court's power to issue orders to enforce judgments extends to all persons whether or not they are parties to the original decree, $273 \mathrm{~F}$. Supp. at 6 , but in the case at bar, the persons who violated the decree were acting in concert with the original parties and therefore were within the scope of rule $65(d)$.

Section 1651 has been used in issuing silence orders prohibiting publications concerning the accused during a criminal trial. See United States v. Schiavo, 504 F.2d 1, 6 n.10 (3d Cir.), cert. denied, 419 U.S. 1096 (1974) (court assumes, without deciding, that a lower court had power to issue a silence order under 18 U.S.C. $\$ 3231$ (1970), granting jurisdiction over "all offenses against the laws of the United States," without examining whether $\S 1651$ authorizes the issuance of "such an essentially injunctive order affecting persons who are not parties in aid of its criminal jurisdiction"). See generally Rendleman, Free Press-Fair Trial: Review of Silence Orders, 52 N.C.L. Rev. 127 (1973); Nebraska Press Ass'n v. Stuart, 96 S. Ct. 2791, 2806 (1976) (questioning but not resolving whether a silence order could restrain publications outside a court's jurisdiction).

${ }^{126}$ In Brown v. Board of Educ., 349 U.S. 294, 301 (1955), the Supreme Court directed district courts to retain jurisdiction over cases during the "period of transition" from a segregated to a racially nondiscriminatory school system. For the limits on a desegregation court's retention of jurisdiction, see Swann v. Charlotte-Mecklenburg Bd. of Educ., 402 U.S. 1, 12, 27-28 (1971).

${ }^{12 \pi}$ See, e.g., Board of Educ. v. York, 429 F.2d 66, 69 (10th Cir. 1970), cert. denied, 401 U.S. 954 (1971); United States v. Farrar, 414 F.2d 936 (5th Cir. 1969).

Compare Brewer v. Hoxie School Dist., 238 F.2d 91, 103 (8th Cir. 1956), where $\$ 1651$ supported the issuance of a permanent injunction against persons who were conspiring to interfere with school desegregation. The purpose of the injunction was not to enforce an outstanding decree, but to protect from deliberate interference the school board's voluntary efforts to comply with Brown. See note 162 infra.

122 See, e.g., Faubus v. United States, 254 F.2d 797 (8th Cir.), cert. denied, 358 U.S. 829 (1958). 
obstruction of justice statute, section 1509 of the Federal Criminal Code, ${ }^{129}$ in part designed to deter and punish violent interference with school desegregation decrees by making such conduct a federal crime. ${ }^{130}$ The legislative history of section 1509 demonstrates the congressional assumption that the judicial contempt power was inadequate to enforce desegregation decrees. ${ }^{131}$ When confronted by mass resistance, courts could not proceed against the leaders or participants for contempt unless they were parties to the original desegregation decree or acting in concert with such parties. ${ }^{132}$ In order for a court to employ the contempt power, a party to the suit had to return to court, and petition for and offer proof warranting a new injunction against identifiable resistance leaders. The contempt sanction could be invoked only if those bound by the new injunction subsequently violated it. ${ }^{133}$ This method was rejected as "a time-consuming procedure . . . of no practical use in producing the prompt action needed." ${ }^{134}$ The statute was designed to reach persons who were not parties to the desegregation decree, but who acted so as to frustrate its enforcement by force or threat of force. Section 1509 thus avoids the jurisdictional limits which had hampered the courts' use of the contempt power as an enforcement tool.

Section 1509 is typically applied in conjunction with the federal criminal statutes designed to protect persons exercising their consti-

12 Act of May 6, 1960, 18 U.S.C. $\$ 1509$ (1970). This section provides:

Whoever, by threats or force, willfully prevents, obstructs, impedes, or interferes with, or willfully attempts to prevent, obstruct, impede, or interfere with, the due exercise of rights or the performance of duties under any order, judgment, or decree of a court of the United States, shall be fined not more than $\$ 1,000$ or imprisoned not more than one year, or both.

No injunctive or other civil relief against the conduct made criminal by this section shall be denied on the ground that such conduct is a crime.

${ }_{130}$ The existing obstruction of justice statute, 18 U.S.C. $\S 1503$ (1970), which punished those who impeded the "due administration of justice," was thought to be inadequate to cover the problems raised by desegregation decrees. Narrow interpretations of "obstructions" of the "due administration of justice" by the courts had raised doubts about the scope of the statute. Civil Rights: Hearings on H.R. 300 Before Subcomm. No. 5 of the House Comm. on the Judiciary, 86th Cong., 1st Sess., 207-08 (1959) (statement of William P. Rogers) [hereinafter cited as Hearings on H.R. 300]. The House report described the primary purpose of the bill as "strengthening the penal law with respect to the obstruction of court orders in public school desegregation cases." H.R. REP. No. 956, 86th Cong., 1st Sess. 1 (1959).

${ }^{131}$ H.R. REP. No. 956, 86th Cong., 1st Sess. 1942 (1959).

${ }^{132}$ Id.

${ }_{133}$ Id.; Hearings on H.R. 300, supra note 130, at 207. See generally Rendleman, supra note 8, at 908-11; Note, Injunctions: Can They Bind Parties Not Mentioned in Rule 65(d)? 35 U. PITT. L. REv. 483, 496-97 (1973); text at notes 114-18 supra.

13 Hearings on H.R. 300, supra note 130, at 207. The use of an ex parte TRO to solve the problem of the "time-consuming procedure" was not considered in the report or hearings. 
tutional rights. ${ }^{135}$ Most section 1509 cases have involved actions which are also state or federal crimes, such as bombing school buses or violently assaulting persons during a protest against a desegregation decree. ${ }^{136}$ In this supplementary stance, section 1509 is not playing the central role in enforcing desegregation decrees envisioned by Congress. A major reason ${ }^{137}$ for this supplementary role is that section 1509's prohibition of "threats or force" does not reach all conduct which courts fear may obstruct the school desegregation process. ${ }^{138}$

The effectiveness of section 1509 is also limited by the procedural requirements of criminal statutes. Although a jury trial is not always necessary for criminal contempt, ${ }^{139}$ it is a requirement under section 1509 unless waived by the defendant. ${ }^{140}$ Another impediment

135 See, e.g., United States v. Griffin, 525 F.2d 710 (1st Cir. 1975) ( $\$ 1509$ used in conjunction with 18 U.S.C. $\$ 245(\mathrm{~b})(4)(\mathrm{A})(1970)$ ); United States v. Hayes, 444 F.2d 472 (5th Cir. 1971), aff'd, 464 F.2d 1252 (5th Cir. 1972); Rosecrans v. United States, 378 F.2d 561 (5th Cir. 1967) ( $\$ 1509$ used in conjunction with 18 U.S.C. $\S 241$ (1970)).

130 United States v. Griffin, 525 F.2d 710 (1st Cir. 1975) (assault during demonstration); United States v. Fruit, 507 F.2d 194 (6th Cir. 1974); United States v. Hayes, 444 F.2d 472 (5th Cir. 1971) (bombing school buses); Rosecrans v. United States, 378 F.2d 561 (5th Cir. 1967) (bombing home of black parents).

${ }_{137}$ Another reason for the limited use of $\S 1509$ may be the nature of the evidence the government must show to obtain a conviction. Because the statute punishes intentional obstruction of a court decree, a defendant must be shown to have had knowledge of the existence of the decree and to have acted with the specific intent to obstruct it. However, this has not been a difficult showing to make. See United States v. Griffin, 525 F.2d 710, 713 (1st Cir. 1975), where the court suggested that it would be possible to infer such knowledge from evidence of publicity given to a desegregation decree, or general neighborhood knowledge of its existence.

${ }^{138}$ E.g., Newburg Area Council, Inc. v. Board of Educ., Nos. 7045 \& 7291 (W.D. Ky., Sept. 6, 1975) (order prohibiting picketing near schools and gatherings along bus routes); United States v. Hall, 472 F.2d 261 (5th Cir. 1972) (contempt citation affirmed for violation of orderly entering public school grounds without authorization); Board of Educ. v. York, 429 F.2d 66 (10th Cir. 1970), cert. denied, 401 U.S. 954 (1971) (injunction against sending child to neighborhood school rather than the school to which he was assigned under the desegregation plan); United States v. Farrar, 414 F.2d 936 (5th Cir. 1969) (injunction against interfering with blacks sending their children to previously "white" schools under a freedom of choice desegregation plan).

130 See note 77 supra.

1to See, e.g., United States v. Fruit, 507 F.2d 194, 195 (6th Cir. 1974) (defendants waived trial by jury in prosecution for violation of $\$ \S 241,1509$ ).

When a defendant is charged with contempt for disobeying a court order, and the act of contempt "also constitutes a criminal offense under any Act of Congress, or under the laws of any state in which it was done," the accused can demand a trial by jury. 18 U.S.C. $\$ 3691$ (1970). Prosecutions for contempts which are also violations of federal or state criminal statutes are brought under 18 U.S.C. $\$ 402$ (1970). See Clark v. Boynton, 362 F.2d 992, 99697 (5th Cir. 1966) (when acts of contempt are also arguably a violation of $\S \S 241,242$, or 1509 , a right to jury trial exists under $\S \S 402,3691$ ).

Exceptions are made for contempts committed in the presence of the court and for contempts in a suit brought for or by the United States. 18 U.S.C. $\S \S 402,3691$ (1970). 
to expeditious enforcement is that an accused can defend by raising constitutional objections, a form of attack unavailable in contempt proceedings because of the collateral bar rule. ${ }^{141}$ Furthermore, as with all federal criminal statutes except contempt, the enforcement of section 1509 depends on the zeal of federal prosecutors, ${ }^{142}$ thus removing a quantum of judicial control over the vindication of judicial authority.

\section{E. The Gap Left by Conventional Remedies}

The federal criminal statutes resurrected or specifically passed to aid the courts in enforcing school desegregation are methods of combating widespread community resistance, but restrictions attending the use of these statutes limit their effectiveness. Section 242 will reach only persons acting under color of law, and it is doubtful that section 241 can reach purely private actions that violate fourteenth amendment rights. Although section 245 does reach purely private actions in derogation of fourteenth amendment rights, it does not apply to nonviolent resistance to desegregation. Section 1509 is also specifically limited in scope to threats or force. Thus, these statutes will not reach purely private nonviolent conduct which creates potentially dangerous and disruptive situations. ${ }^{143}$ Some examples of this "gap" in coverage are gatherings or picketing near school grounds or along bus routes, strong speech which does not rise to the level of incitement or threat, economic pressures, and refusing to send children to newly assigned schools. ${ }^{144}$

A court can control conduct which escapes these statutory proscriptions by issuing injunctive orders to protect its judgments, but the use of injunctions is strictly limited. The requirements of rule 65 may thwart the court's ability to render effective protection in the face of widespread, organizationally diffuse community resistance to the decree. Injunctive relief in the school desegregation context is suitable for preventing long-term interference by those definable groups who would repeatedly attempt to hinder enforcement of the decree, but as a method of stopping intermittent disruptive behavior from diverse elements of the community, injunctive orders are particularly ineffective. Temporary restraining orders avoid the

141 See note 81 supra.

112 See I Nat'l Comm'n on Reform of the Federal Criminal Laws, Working Papers 602 , 605 (1970). See also United States v. Cox, 342 F.2d 167 (5th Cir. 1965).

113 The first amendment may present an important obstacle to extending these statutes to reach such conduct. See note 11 supra; note 199 infra.

is See note 138 supra. 
notice and hearing requirements of preliminary and permanent injunctions, but are effective for only ten days. Furthermore, they are sparingly granted and, like injunctions, are binding only on those named in the order, their agents, and those in active concert with them. Unless a court can identify in advance those who are likely to attempt to interfere with the decree, injunctive orders will not effectively control mass community resistance.

Courts whose judgments are imperiled by angry and uncooperative communities have faced a "gap" in the enforcement remedies available to counter resistance from an undefinable class. Some judicial responses to this gap and the difficulties they raise can now be considered.

\section{Judicial Responses to the Perceived Inadequacy of Conventional Remedies}

\section{A. The Undefinable Class Order}

In response to the perceived inadequacy of conventional remedies for community resistance to school desegregation, some courts have used an additional remedy-the undefinable class order. ${ }^{145}$ These orders share some of the characteristics of the more conventional methods of enforcing judgments, but the differences make their validity suspect. ${ }^{146}$ Undefinable class orders typically describe the persons to be bound in terms of the activity which is proscribed. Courts issuing these orders seek to bind an entire community by using such phrases as "all persons shall" or "no person shall". There is no provision for notice and hearing prior to the issuance of an order. Those affected by the order typically will not receive a day in court until contempt proceedings for a violation of the order are held, ${ }^{147}$ at which time the collateral bar rule prevents the contemnor

is E.g., Newburg Area Council, Inc. v. Board of Educ., Nos. 7045 \& 7291 (W.D. Ky., July 30, 1975; Sept. 6, 1975); Lynch v. Snepp, 350 F. Supp. 1134 (N.D.N.C. 1972), rev'd on other grounds, 472 F.2d 769 (4th Cir. 1973), cert. denied, 415 U.S. 983 (1974); Stell v. Board of Educ., No. 1316 (S.D. Ga., March 16, 1972); Mims v. Duval County School Bd., 338 F. Supp. 1208 (M.D. Fla. 1971), supplemented, 350 F. Supp. 553 (1972).

"s See, e.g., Newburg Area Council, Inc. v. Board of Educ., Nos. 7045 \& 7291 (W.D. Ky., Sept. 2, 1975; Sept. 6, 1976) (the first order, like a TRO, expired in ten days on its own terms; the second order had no such resemblance to a TRO); Stell v. Board of Educ., No. 1316 (S.D. Ga., March 16, 1972) (order declared to be a TRO complies with virtually none of rule 65(b)'s requirements for the issuance of ex parte TROs).

ist A member of an undefinable class theoretically could request the issuing court to dissolve, modify, or clarify the order. See, e.g., Lynch v. Snepp, 350 F. Supp. 1134 (W.D.N.C. 1972), rev'd on other grounds, 472 F.2d 769 (4th Cir. 1973), cert. denied, 415 U.S. 983 (1974), (state court injunction challenged). However, he may be denied standing to litigate the issue of whether he is bound under the order, or prevented from intervening in the underlying suit 
from attacking the order's substantive validity. ${ }^{148}$

1. Hall $v$. United States. In Harrington $v$. Colquitt County Board of Education, ${ }^{149}$ a direct appeal was taken from an order enjoining named parties and "all persons who are residents of Colquitt County" from interfering with a desegregation judgment. ${ }^{150}$ The Fifth Circuit held that the language enjoining the undefinable class of residents was "impermissibly broad," and voided the offending language, citing rule $65(\mathrm{~d})$. The portion of the order which bound persons within the limits of rule 65(d) was upheld. ${ }^{151}$

One year later, in Hall $v$. United States, ${ }^{152}$ the Fifth Circuit approved an undefinable class order as a response to the difficult enforcement problems of school desegregation. Hall involved an order issued by the district court in Mims v. Duval County School Board ${ }^{153}$ in response to allegations by the school superintendent and the sheriff that outsiders were causing disruptions and violence in a recently desegregated school. The order "enjoined and restrained" a definable class of school children ("all students of Ribault High School") ${ }^{154}$ and an undefinable class of persons ("other persons acting independently") from doing specified acts, some of which were beyond the reach of state and federal criminal laws and local ordinances. ${ }^{155}$ Immediately after issuing the order, the court ordered the sheriff to serve copies of the order on seven named persons, includ-

at the injunction stage. See United States v. Wilhelm Reich Foundation, 17 F.R.D. 96 (D. Me. 1954), aff'd sub. nom. Baker v. United States, 221 F.2d 957 (1st Cir.) (per curiam), cert. denied, 350 U.S. 842 (1955). Alternatively, the plaintiff could join him as a named defendant; he would then be able to challenge the validity of the order, but not whether he is subject to it.

If the order is a TRO, it is ordinarily not a final order for the purpose of appeal. See, e.g., Smith v. Jackson State College, 441 F.2d 278, 279 (5th Cir. 1971) (per curiam).

14. See note 81 supra.

tง 449 F.2d 161 (5th Cir. 1971) (per curiam).

150 Id.

ist Id.

t52 472 F.2d 261 (5th Cir. 1972). This case is discussed in Note, Injunctions: Can They Bind Parties Not Mentioned in Rule 65(d)? 35 U. PrTT. L. REv. 483 (1973); 26 Vand. L. Rev. 625 (1973).

133338 F. Supp. 1208 (M.D. Fla. 1971); see text and notes at notes 13-18 supra.

is It is likely that the described class of school children could have been named individually, but unclear that they could be bound as a class under rule 65(d). See note 95 supra.

155472 F.2d at 263 . The specific acts prohibited were: (1) obstructing class attendance; (2) harassing faculty and staff; (3) harassing any student en route to and from school; (4) vandalizing school property; (5) entering school grounds without authorization; and (6) disrupting the orderly operation of a school. The order provided that "[a]nyone having notice of this order who violates any of the terms thereof shall be subject to arrest, prosecution and punishment . . for criminal contempt." Id. 
ing Eric Hall. ${ }^{156}$ It is clear that both the petitioners and the court had identified Hall as one of the leaders of the "Black Front," a group that had expressed its opposition to the desegregation plan. Hall was not named as a party to the order, nor was he found to be in active concert with either the parties to the desegregation suit or the definable class of students described in the order. ${ }^{157}$ Four days after the order was issued, Hall appeared on the school grounds for the purpose of violating the decree, was arrested, and subsequently convicted for contempt.

The Fifth Circuit recognized that inclusion by description in an order subsequent to a desegregation judgment did not join Hall as a party to the desegregation suit. ${ }^{158}$ In order to uphold Hall's contempt conviction, the court had to reconcile the "all persons" language of the order with the acknowledgment in Harrington that rule 65's "scope" limitations apply to desegregation enforcement orders purporting to bind entire communities. The court distinguished Harrington on the ground that the order there was a permanent injunction, in contrast to the order in $\mathrm{Hall}$, which the court "characterized" as a TRO ${ }^{159}$ because it had been violated within ten days after issuance. The court conceded that the order was subject to the notice and hearing requirements codified in rule 65 , but declared that the order was within rule 65(b), which permits temporary restraints to issue ex parte. However, the court failed to examine whether the order met rule 65(b)'s requirements for the issuance of ex parte TROs, and there is no indication that the order did satisfy the statute's terms. ${ }^{160}$

Even if the order in Hall satisfied the notice and hearing requirements of rule 65(b), ex parte TROs are still subject to the scope requirements of rule $65(\mathrm{~d})$ : only named parties, their agents, and those acting in concert with them are bound by a TRO. Eric Hall did not fit into any of these categories. The Fifth Circuit did not

158 The fact that Hall received notice by personal service suggests that the situation in Hall was very similar to that in Kasper v. Brittain, 245 F.2d 92 (6th Cir.), cert. denied, 355 U.S. 834 (1957), discussed at note 116 supra. In both cases the court could identify the leaders of the incipient resistance to a desegregation decree. But in Kasper, the leader was named and served with notice before the order was issued.

137472 F.2d at 266.

15x Id. at 262

150 Id. at $267-68$

16n The facts that the petition identified Eric Hall as one of the disrupters and that the court ordered the sheriff to serve Hall with a copy of the order immediately after issuance indicate that Hall could have been given notice prior to the issuance of the order. There is no evidence that the petitioners complied with rule 65(b)'s requirement of certifying attempts to notify Hall and reasons why notice should be excused. 
attempt to characterize Hall as a "party" for the purposes of rule 65 , but instead suggested that the order came within an implied exception to the personal jurisdiction requirements of the rule. The court offered several explanations for the existence of this exception, based on general equitable principles and the special enforcement problems of desegregation suits.

The court found that Hall had threatened both the plaintiffs' constitutional right and the defendants' constitutional duty as adjudicated in Mims. Asserting that a court has "fundamental power to make a binding adjudication between the parties properly before it," 161 the panel distinguished the cases on which Hall had relied for the common law rule that a nonparty who violates an injunction cannot be held in contempt. ${ }^{162}$ The court invoked United States $v$. United Mine Workers ${ }^{163}$ to support a court's "inherent jurisdiction to preserve . . . [the] ability to render judgment."164 United Mine Workers held that a court has jurisdiction to issue preliminary orders to preserve the status quo pending a determination of its jurisdiction to grant further relief. The Hall court's use of United Mine Workers to justify orders addressed to "all persons acting independently" is an unwarranted extension of that case in two respects. First, the United Mine Workers doctrine has been limited to cases where subject matter rather than in personam jurisdiction

161472 F.2d at 265.

${ }^{182}$ Id. at 264-65. The court noted with approval Chase Nat'l Bank v. City of Norwalk, 291 U.S. 431 (1934), and Alemite Mfg. Corp. v. Staff, 42 F.2d 832 (2d Cir. 1930), where injunctions attempting to bind nonparties acting independently were invalidated, but insisted that "[t]his case is different." In Alemite and Chase, the activities of third persons 'would have harmed only the plaintiffs' interests. In contrast, the acts of Eric Hall impaired not only the plaintiffs' rights but also the defendant school board's ability to fulfill their obligations as defined in the desegregation decree.

The court cited Brewer v. Hoxie School Dist., 238 F.2d 91 (8th Cir. 1956), to support its argument that the facts in Hall justified the lower court's order. Brewer was the first case in which a federal district court asserted the power to issue injunctions to protect the process of school desegregation against private interference. The school board had fashioned a desegregation plan on its own initiative rather than in compliance with the court order. Id. at 93 . Private individuals threatened school board members, made inflammatory speeches urging mass resistance, and proposed a boycott of the schools. The school board obtained an injunction prohibiting obstructive actions by these persons. In answer to the contention that it lacked subject matter jurisdiction to enjoin the actions, the court held that it derived federal question jurisdiction from the right of school board members to be free from interference "with the performance of the constitutionally imposed duty." Id. at 99 . Because the school board had sworn to uphold the Constitution, it had a federally protected right to be free from intentional interference with its attempt to comply with the mandate of Brown. Id. In Brewer, the order enjoined only named parties, not an undefinable class, and thus is consistent with Alemite and Chase. Id. at 93.

163330 U.S. 258, 293 (1947).

18: United States v. Hall, 472 F.2d 261, 265 (5th Cir. 1972). 
is in doubt. ${ }^{165}$ Second, the court ignores the distinction between orders designed to preserve the status quo pending the determination of a court's power to adjudicate rights and duties, and orders designed to protect a judgment already rendered when its enforcement or satisfaction is threatened. ${ }^{166}$

The court in Hall invoked the need for "broad applications of the power to punish for contempt . . . if courts are to protect their ability to . . . make their remedial orders effective." ${ }^{167}$ If the court is suggesting the existence of a generalized contempt power to enforce its judgments, it seeks a truly radical expansion of the contempt power. Under section 401(3) of the Federal Criminal Code, a court possesses the power to punish "disobedience or resistance to its lawful writ, process, order, rule, decree, or command."168 The contempt power codified in section 401 is not an unlimited grant of punitive authority. ${ }^{169} \mathrm{Judicial}$ orders, in contrast to legislative enactments, prohibit or mandate only the actions of the specific individuals whose rights and duties have been adjudicated, and those persons in special relations to such individuals. ${ }^{170}$ Thus, in Chase

ics See Z. Chafee, Some Problems of Equity 374 (1950); Cox, The Void Order and the Duty to Obey, 16 U. CHI. L. Rev. 86, 100 (1948); Rendleman, supra note 8, at 921-22; Rogers, The Elusive Search for the Void Injunction: Res Judicata Principles in Criminal Contempt Proceedings, 49 B.U.L. REv. 251, 272-73 (1969).

14" See Note, Injunctions: Can They Bind Parties Not Mentioned in Rule 65(d)? $35 \mathrm{U}$.

PitT. L. Rev. 483, 490-91 (1973).

107 472 F.2d at 266.

128 18 U.S.C. $\S 401$ (1970), states:

A court of the United States shall have power to punish by fine or imprisonment, at its discretion, such contempt of its authority, and none other, as-

(1) Misbehavior of any person in its presence or so near thereto as to obstruct the administration of justice;

(2) Misbehavior of any of its officers in their official transactions;

(3) Disobedience or resistance to its lawful writ, process, order, rule, decree, or command.

This statute codifies the common law contempt power. For examples of cases invoking an inherent contempt power, see Bessette v. W.B. Conkey Co., 194 U.S. 324, 327 (1904); Ex parte Robinson, 86 U.S. (19 Wall.) 505, 510 (1873). For a general discussion of the history of the inherent contempt power, see Frankfurter \& Landis, Power of Congress over Procedure in Criminal Contempts in "Inferior" Federal Courts-A Study in Separation of Powers, 37 HaRv. L. Rev. 1010, 1023-58 (1924).

16" Some courts have misconceived the notion of "disobedience or resistance." See, e.g., In re Lennon, 166 U.S. 548 (1897); Russell v. United States, 86 F.2d 389 (8th Cir. 1936); United States v. Shipp, 214 U.S. 386 (1909); Chisholm v. Caines, 121 F. 397 (D.S.C. 1903); In re Reese, 107 F. 942 (8th Cir. 1901); Seaward v. Paterson, [1897] 1 Ch. 545 (C.A.). A person cannot be said to "disobey" an instruction unless he has been ordered to obey it. Similarly, "resistance" is properly limited to instances where a person had been ordered not to resist. See Alemite Mfg. Corp. v. Staff, 42 F.2d 832, 833 (2d Cir. 1930) ("II]t is not the act described which the decree may forbid, but only that act when the defendant does it").

130 One of the faults of injunctive orders that purport to bind the world is the transmuta- 
National Bank $v$. City of Norwalk, ${ }^{171}$ the Supreme Court indicated that the existence of a generalized contempt power binding the community at large to refrain from "disobedience or resistance" to a court's order was contrary to "established principles of equity jurisdiction and procedure." 172 This result has been codified in rule $65(d)^{173}$ and cannot be bypassed by cryptic references to a court's need to be able to make an effectively binding adjudication.

The court found additional support for an exception to the requirements of personal jurisdiction in the unique nature of school desegregation decrees. One argument sought to establish that desegregation decrees are analogous to in rem injunctions, which are "binding on all persons, regardless of notice." 174 Like a court adjudicating rights in a piece of property, a desegregation court "is necessarily faced with the danger that its judgment may be disrupted in the future by members of an undefinable class." 175 The court reasoned from the similar enforcement problems of in rem and school desegregation judgments to conclude that school desegregation decrees should not be strictly limited by the requirements of in personam jurisdiction. ${ }^{176}$ In rem injunctions are an example of common law contempt jurisdiction over strangers to a judgment that has not been completely extinguished by rule $65(\mathrm{~d}) .{ }^{177}$ However, the exception is a narrow one, ${ }^{178}$ and the similarity of desegregation enforcement orders to the in rem exception does not convincingly advance

tion of the judicial process into a legislative process. "A particular controversy between particular parties-which is the limited sphere of judicial power-is made the occasion for a code of conduct governing the whole community." F. Frankfurter \& N. GreEne, The LABOR INJUNCTION 126 (1930); see Rendleman, supra note 8, at 926-33.

171291 U.S. 431 (1934).

172 Id, at 436-37.

${ }^{173}$ See Zenith Radio Corp. v. Hazeltine Research, Inc., 395 U.S. 100 (1969); Regal Knitwear v. NLRB, 324 U.S. 9, 13 (1945).

174 472 F.2d at 266. See generally Dobbs, Contempt of Court-A Survey, 56 CoRneld L. Rev. 183, 257-59 (1971); Rendleman, supra note 8, at 911-16.

173472 F.2d at 266.

${ }^{176}$ The court was apparently unwilling to adopt the in rem analogy in its entirety. A nonparty who is ignorant of an in rem injunction can be held in contempt. See, e.g., Silvers v. Traverse, 82 Iowa 52,47 N.W. 888 (1891). In Hall, the court emphasized that the defendant had violated the order with actual notice of its terms. 472 F.2d at 267 .

177 See Rendleman, supra note 8, at 919-20,927. The in rem theory has been vigorously attacked as a violation of rule $65(\mathrm{~d})$ and of due process requirements. See, e.g., Dobbs, Contempt of Court-A Survey, 56 CoRnell L. Rev. 183, 257-59 (1971); cf. McKinney v. Alabama, 424 U.S. 669 (1976) (state in rem proceeding held inadequately protective of first amendment rights of those not in privity with the in rem defendants).

${ }^{17 \times}$ Bankruptcy courts use a limited version of the in rem injunction. See 7 MOORE's Fridrat. Practice If 65.13, at 65-112 n.11 (2d ed. 1975). The cases cited in Hall to support the use of in rem injunctions are almost all bankruptcy cases. 472 F.2d at 266. 
the court's assertion that the enforcement orders at bar constitute another distinct exception to the rule. ${ }^{179}$

The court tied its analogy between desegregation orders and actions in rem to the need for "broad and flexible remedial powers" to achieve school desegregation. ${ }^{180}$ Citing the Supreme Court's recognition of a desegregation court's expansive equity powers in Swann v. Charlotte-Mecklenburg Board of Education, ${ }^{181}$ the court in Hall affirmed a broad power to issue enforcement orders binding an undefinable class. The opinion in Swann did emphasize the "enhanced" equity powers that a district court could employ once a constitutional violation had been found and a school board had defaulted in its obligation to correct it. ${ }^{182}$ But the Court was considering only the nature and scope of affirmative duties that could be imposed on parties to a desegregation suit and did not consider the restraints or duties that could be imposed on persons who are not parties to a desegregation suit. The Supreme Court has never asserted or implied that "enhanced equity powers" in the school desegregation context release a court from the traditional requirements of personal jurisdiction.

The Fifth Circuit offered yet another characteristic of school desegregation judgments to support its contention that enforcement orders addressed to an undefinable class constitute an exception to the requirements of personal jurisdiction. The court argued that Hall was bound under rule 65(d) by virtue of the desegregation decree in Mims, over which the district court had retained jurisdiction. ${ }^{123}$ There is no assertion that Hall was a "party" to the Mims litigation. Rather, the court insisted that "[b]y deciding Mims and retaining jurisdiction the district court had, in effect, adjudicated the rights of the entire community." 184 As a member of that community, Hall stood in a relationship to the decree "within that contemplated by Rule 65(d)."185 To assert that the court could bind

173 The Hall court's comparison of school desegregation enforcement orders to in rem injunctions has been vigorously criticized. See Rendleman, supra note 8, at 919; Note, Injunctions: Can They Bind Parties Not Mentioned in Rule 65(d)? 35 U. PITT. L. Rev. 483, 492 (1973).

ixa $472 \mathrm{~F} .2 \mathrm{~d}$ at 266.

เxı 402 U.S. 1, 6, 15 (1971).

$1 \times 2$ Id. at 15.

100 472 F.2d 261, 266. The district court had retained jurisdiction "to enter such further orders as might be necessary to effectuate its judgment." Id. at 262; see note 126 supra.

ixs 472 F2d at 267.

זxs Id. See also Coffey v. Braddy, 372 F. Supp. 116 (M.D. Fla. 1971), which affirmed an injunction enforcing a decree prohibiting discriminatory employment practices against "anyone having notice of this order who violates any of the terms thereof." The court relied on 
Hall merely because he was a member of the community whose rights had been "adjudicated" is plainly contrary to the language and purpose of rule 65(d). ${ }^{186}$ Hall's membership in the community does not make him a named party to the desegregation decree, an agent of a named party, or one in active concert with a named party. To characterize a desegregation decree as "adjudicating" the rights and duties of an entire community is tantamount to endorsing a legislative role for the courts. ${ }^{187}$ While such an endorsement reflects the enormous pressures on desegregation courts, these pressures do not justify distortions of judicial power or an abrogation of traditional procedural safeguards.

In a final effort to avoid applying the plain language of rule $65(d)$, the court argued that resistance by an undefinable class "was not a situation which could have been anticipated by the draftsmen of procedural rules." 188 But an examination of the legislative history of rule $65(\mathrm{~d})$ rebuts such a contention. The drafters of the Clayton Act, from which rule 65(d) was taken, worked in a context in which labor injunctions governing "all persons" were frequently used to combat similar problems of controlling mass resistance. ${ }^{189}$

The Hall opinion leaves the rule and rationale of the case unclear. ${ }^{190}$ Since Harrington was distinguished on notice and hearing rather than scope grounds, the court avoided explicitly defining the

Mims and Hall, noting that the use of the order in Hall to reach persons acting independently was limited to situations in which those "acting independently" are "identified with parties before the court." Id. at 125 n.2; cf. Environmental Defense Fund v. Environmental Protection Agency, 485 F.2d 780, 784 n.2 (D.C. Cir.) (nonparties had an "identity of interest" with parties), aff'd by an equally divided court sub nom. Fri v. Sierra Club, 412 U.S. 541 (1973), citing United States v. Hall, 472 F.2d 261 (5th Cir. 1972) see note 95 supra.

ins This theory is very close to the now discredited "obstruction of justice" theory of contempt, under which a stranger who knowingly violates the terms of an injunction may be held in contempt for interfering with the administration of justice. See generally 0 . Fiss, InJUNCTIONS 621-25 (1972); Rendleman, supra note 8, at 901-11.

1 in See note 170 supra.

1*8 472 F.2d at 267.

1x' See text and notes at notes 86-87 supra.

199 A subsequent application of $\mathrm{Hall}$ illustrates this confusion. Herrlein v. Kanakis, 526 F.2d 252 (7th Cir. 1975), is the only case which has directly considered the impact of Hall on binding nonparties to injunctive orders. Herrlein refused to extend Hall's implied exception to the language of rule $65(\mathrm{~d})$ to successors in interest of a business owned by an injunction defendant when such business was transferred before the injunction had issued. The Herrlein court viewed the order in Hall as "akin to injunctions issued by courts . . . prohibiting certain conduct within the area of courthouses." Id. at 255. This reference to direct contempt, see Dobbs, Contempt of Court: A Survey, 56 CoRnEll L. REv. 183, 186 (1971), is puzzling, since this variety of contempt was not mentioned in the Hall opinion. The Herrlein opinion also emphasized the enforcement context of Hall as a means of distinguishing it from the case at bar, but did not satisfactorily explain why the enforcement context should alter the requirements of rule $65(\mathrm{~d}) .526$ F.2d at 255 . 
limits of rule 65(d)'s relevance to enforcement orders directed to an undefinable class. Hall purports to stand only for the narrow proposition that desegregation enforcement orders addressed to an undefinable class are valid if they can be characterized as temporary restraints. But even this narrow holding cannot be reconciled with the jurisdictional limit on equitable power codified in rule 65(d).

2. Newburg, Area Council, Inc. v. Board of Education. In Newburg Area Council, Inc. v. Board of Education, ${ }^{191}$ the district court responded to the problem of enforcing its desegregation decree in much the same way as the district court in Mims. Both courts issued orders directed to all persons, with no set expiration date, enforceable by criminal contempt. ${ }^{192}$ However, the Newburg Area Council orders are novel in several respects. The first set of orders directed to the community at large were appended to the desegregation plan. Rather than waiting for actual acts of interference to occur, the court issued these orders sua sponte, in response to publicly declared threats of resistance. ${ }^{193}$ These orders were modified and supplemented after the plan was implemented. Some of the activities proscribed were assembling in or near any public school building without authorization by school authorities, gathering in groups of three or more along school bus routes, and interfering with any person performing his duty under the desegregation decree. ${ }^{194}$ The order technique allowed the court to issue detailed restrictions tailored to the problems it perceived, a flexibility that statutory proscriptions could not provide. ${ }^{195}$ The court did not hold adversary hearings with anyone who would be affected by its "all persons"

191 Newburg Area Council, Inc. v. Board of Educ., 489 F.2d 925 (6th Cir. 1973), vacated and remanded, 418 U.S. 918 (1973), opinion reinstated with modifications, 510 F.2d 1358 (6th Cir. 1974), cert. denied, 421 U.S. 931, mandamus issued, 521 F.2d 578 (1975) (requiring approval of desegregation plan).

${ }^{102}$ See United States v. Hall, 472 F.2d 261, 263 (5th Cir. 1972) (discussing the Mims order); Newburg Area Council, Inc. v. Board of Educ., Nos. 7045 \& 7291 (W.D. Ky., July 30, 1975 ; Sept. 6, 1975). It is unclear whether violation of the order of July 30 would be punished by criminal contempt since the court refers to "federal custody and federal enforcemen't proceeding," without specifying the relevant statutory authority. The order of September 6, however, states explicitly that criminal contempt is the sanction for disobedience.

is3 Newburg Area Council, Inc. v. Board of Educ., Nos. 7045 \& 7291 (W.D. Ky., July $30,1975)$.

19 Newburg Area Council, Inc. v. Board of Educ., Nos. 7045 \& 7291 (W.D. Ky., July 30, 1975; Sept. 6, 1975).

195 "[T]his plan details what actions and activities are considered by the Court to be vital to the successful implementation of the plan and what acts in violation thereof will be treated . . . as obstacles . . . to the appropriate implementation of the plan . . . Newburg Area Council, Inc. v. Board of Educ., Nos. 7045 \& 7291 (W.D. Ky., July 30, 1975). 
orders, instead relying extensively on judicial notice. ${ }^{196}$

In contrast to the order involved in Hall, the majority of the orders in Newburg Area Council cannot be characterized as temporary restraints. ${ }^{197}$ The orders which abolished certain protest zones and prohibited assemblies of more than three persons along school bus routes not only lacked any explicit ten-day limit but remained in force for one year. Thus, the district court in Newburg Area Council cannot rely on Hall to avoid the requirement that notice and hearing be afforded prior to the issuance of the orders.

The Newburg Area Council orders directed to "any person" are subject to the same personal jurisdiction objections as the orders invalidated in Harrington and upheld in Hall. In trying to bind an undefinable class, these courts have, despite their disclaimers, made all the world with notice of their orders potential contemnors. Even if these orders could be characterized as TROs, they would be invalid exercises of injunctive power. A person cannot be bound to an ex parte decree unless he is a party or legally related to a party within the meaning of rule $65(\mathrm{~d})$. Allowing a class of "all those acting independently" to be considered a valid description of "party" for the purposes of rule 65(d) stretches the notion of "party" beyond the breaking point.

3. First Amendment Infirmities of Undefinable Class Orders. The procedural defects of undefinable class orders regulating speech and assembly also create distinct first amendment problems. The use of "all persons" injunctions to enforce school desegregation has on several occasions dramatically restricted speech and assembly opportunities for an entire community. ${ }^{198}$ This tendency to over-

${ }^{198}$ E.g., Newburg Area Council, Inc. v. Board of Educ., Nos. $7045 \& 7291$ (W.D. Ky., Sept. 2, 1975).

${ }^{197}$ E.g., Newburg Area Council, Inc. v. Board of Educ., Nos. 7045 \& 7291 (W.D. Ky., July 30, 1975; Sept. 6, 1975).

${ }^{19 x}$ E.g., Newburg Area Council, Inc. v. Board of Educ., Nos. 7045 \& 7291 (W.D. Ky., Sept. 6, 1975) (order abolished all protest areas near schools, prohibited groups of more than three from walking along bus routes, prohibited any person from entering school grounds without official permission, and required a school board member to jam citizens' band radio channels); United States v. Hall, 472 F.2d 261, 263 (5th Cir. 1972) (district court order prohibited any person from entering school grounds without permission from authorities).

In Lynch v. Snepp, 350 F. Supp. 1134, 1140-43 (W.D.N.C. 1972), rev'd on other grounds, 472 F.2d 769 (4th Cir. 1973), cert. denied, 415 U.S. 983 (1974), the district court held that an "all persons" enforcement order similar to those issued in Hall and Newburg Area Council prohibiting entry onto school property without official permission was an invalid prior restraint on first amendment rights. In Barnhardt v. Meridian, 394 F.2d 454, 455 (5th Cir. 1968), a similar issue was raised when the plaintiffs and intervenor contended that the "attempt to enjoin all private individuals . . . is an unconstitutional restriction of protected activities and violative of the First Amendment." The court was, however, able to avoid 
broad restriction is closely linked to the undefinable class character of such orders. ${ }^{199}$

The central importance of procedural safeguards in the issuance of TROs was emphasized in Carroll $v$. President \& Commissioners of Princess Anne County, ${ }^{200}$ where a temporary restraint was issued ex parte by a state circuit court ${ }^{201}$ to prevent several named members of the National States Rights Party and the organization itself from making speeches. ${ }^{202}$ In Carroll, it was entirely possible to serve notice on the enjoined parties, ${ }^{203}$ thus obtaining personal jurisdiction and affording a chance to contest the issuance of the order. Justice Fortas's majority opinion noted the special importance of procedural safeguards when prior restraints are involved, ${ }^{204}$ and asserted that the presumption against prior restraints may be overcome only when "careful procedural provisions, designed to assure the fullest presentation and consideration of the matter which the circumstances permit" have been used. ${ }^{205}$ The Court concluded that since notice before issuance was possible, the protection of first amendment rights required that such notice be given. If notice is

deciding this question by holding that an "any other person" order was an impermissible deviation in policy from the model desegregation plan set forth in United States v. Jefferson County Bd. of Educ., 372 F.2d 836 (5th Cir. 1966), cert. denied, 389 U.S. 840 (1967).

i' The restrictions on expressive activity contained in the Newburg Area Council and Morgan $v$. Kerrigan orders also raise questions of substantive first amendment law. These questions have been treated elsewhere and are beyond the scope of this comment. See generally Blasi, Prior Restraints on Demonstrations, 68 Mich. L. Rev. 1481 (1970); Monaghan, First Amendment "Due Process," 83 Harv. L. Rev. 518 (1970); Comment, The First Amendment Overbreadth Doctrine, 83 HaRv. L. Rev. 844 (1970); Comment, Less Drastic Means and the First Amendment, 78 YALE L.J. 464 (1969).

200393 U.S. 175 (1968).

${ }^{201}$ Because the order was issued by a state court, the requirements of rule 65(b) did not apply.

${ }^{202}$ Local officials were concerned that racial tensions in the area would lead to violence if the meeting was held; unrest at a previous rally had provided evidence of such danger. 393 U.S. at 176-77.

${ }^{203} I d$. at 182-83. Several named addressees of the order were served with copies the same day the order was issued.

201 Id. at 181.

${ }^{205}$ Id. One commentator has argued that Carroll has proven easy to distinguish. Rendleman, Toward Due Process in Injunction Procedure, 1973 U. ILL. L.F. 221, 229-30. Rendleman suggests that Carroll has been invoked only when pure speech, rather than the mixture of speech with conduct known as "speech plus," was restrained, and when the order is attacked directly rather than collaterally. He argues that these limitations have reduced the salutary effect of Carroll. Id. at 229. But in McKinney v. Alabama, 96 S. Ct. 1189 (1976), a state in rem proceeding against certain pornographic magazines was held inadequately protective of the first amendment rights of those not in privity with the in rem defendants. The Supreme Court allowed collateral attack of the in rem injunction, stressing the importance of true adversary proceedings in the first amendment context. However, the case did not involve "speech plus," nor did the Court cite Carroll. 
possible, but not provided, the "careful procedural provisions" necessary to overcome the presumption against prior restraints are not present. ${ }^{206}$

In Carroll, the Supreme Court reasoned that when the Constitution demands a refined tailoring of restraints to accommodate conflicting interests, the accuracy of the factual situation to which the restraints must be "tailored" 207 assumes special importance. When an order purports to bind "all those acting independently" and is issued without any adversary hearing, precise tailoring of the restraint is unlikely. ${ }^{208}$ First amendment interests are afforded better protection in an adversary context where, on the basis of more detailed and certain factual information concerning specific parties before the court, a fuller picture of the competing interests can emerge. ${ }^{209}$ But it is impossible to hold an adversary hearing for each member of an undefinable class before an order is issued, and it is unclear that any number of "representative" adversary hearings will in fact be representative or adequately protective of the interests affected by an order directed to an entire community.

In both Hall and Carroll, the petitioners had identified certain individuals as the primary targets of the restraining orders. Nonetheless, both courts failed to give notice to those individuals before

${ }^{206}$ Judgment as to whether the facts justify the use of the drastic power of injunction necessarily turns on subtle and controversial considerations and upon a delicate assessment of the particular situation. . . . In the absence of evidence and argument offered by both sides, there is insufficient assurance of the balanced analysis and careful conclusions which are essential in the area of First Amendment adjudication . . . .

... [T]he order must be tailored as precisely as possible to the exact needs of the case. . . . [T] he failure to invite participation of the party seeking to exercise First Amendment rights reduces the possibility of a narrowly drawn order, and substantially imperils the protection which the Amendment seeks to secure.

393 U.S. at 183.

${ }^{207}$ See Grayned v. City of Rockford, 408 U.S. 104, 115-21 (1972); Albany Welfare Rights Organization v. Wyman, 493 F.2d 1379 (2d Cir. 1974).

Rule 65(d) also contains a "tailoring" requirement, providing that all injunctive orders must be "specific in terms" and "describe in reasonable detail . . . the act or acts sought to be retrained." Orders that prohibit all actions that "in any way" interfere with a desegregation decree, see note 4 supra, are thus impermissible under rule $65(d)$ as well as vulnerable to first amendment overbreadth attack.

20x See Rendleman, Toward Due Process in Injunction Procedure, 1973 U. ILL. L.F. 221, 236-37; Comment, Collateral Attack of Injunctions Restraining First Amendment Activity, 45 S. Cal. L. Rev. 1083, 1099 (1972).

209 One commentator has suggested that regulation of speech by injunction is less repressive than licensing requirements, since "the burden of initiative is on the censor . . . ; there is less ambiguity about who is covered; and the original decision is made by a judge after an adversary proceeding." Blasi, Prior Restraints on Demonstrations, 68 Mich. L. Rev. 1481, 1558 (1970). In Newburg, none of these characteristics were present: the orders issued sua sponte, they purported to bind the entire community, and no adversary hearing was held. 
issuing orders purporting to bind them. The order in Hall, issued by a federal district court, was subject to the requirements of rule 65 . Since the TRO involved in Carroll was issued by a state court, the Supreme Court could not invoke rule 65 and instead relied on the first amendment defects of the ex parte procedure to invalidate the order. Carroll effectively makes rule 65(b)'s notice-when-possible standard a constitutional requirement in the first amendment context. Under this standard Hall should have been named in the order and given notice and an opportunity to be heard prior to the issuance of the restraint on his protest activities on the school grounds. Following this procedure would have made the injunction consistent with rule 65 and provided the first amendment protections stressed in Carroll.

In Newburg Area Council, it would have been more difficult for the court to comply with the requirements of rule 65 . Unlike Hall and Carroll, where the pattern of and participants in disruptions had already been established, the court in Newburg Area Council imposed some restraints before any acts of resistance had occurred. ${ }^{210}$ Judge Gordon did note, however, that "certain individuals in our community have publicly declared their intended resistance, by use of force if necessary."211 This suggests that the court could have made a list of persons likely to disrupt the desegregation decree, similar to the list of named addressees in Carroll and the list of individuals to be notified that was given to the sheriff in Hall.

If such a list of potential resisters had been compiled, the identified individuals could have been named as parties and given notice and an opportunity for a hearing prior to the issuance of the order. Other resisters acting independently could not be bound until they could be identified and named in subsequent orders. The Newburg Area Council court's failure to follow this process of gradually identifying sources of possible resistance precluded the satisfaction of rule 65's notice and hearing requirements. Unless a person is named as a party to an injunction, that person cannot receive the notice and opportunity for a hearing that is protected by rule 65(a). Nor can the conditions that limit the issuance of ex parte TROs under rule 65 (b) be satisfied. A court cannot avoid the requirement of notifying the adverse parties on the ground that the "parties" are unknown members of an undefinable class. The failure of the court in Newburg Area Council to comply with rule 65 also fails to com-

${ }_{210}$ See note 22 supra.

211 Newburg Area Council, Inc. v. Board of Educ., Nos. 7045 \& 7291 (W.D. Ky., July 30, 1975). 
port with Carroll's insistence on the importance of prior notice and hearing in the first amendment context.

\section{B. Indirect Regulation}

In Morgan $v$. Kerrigan, ${ }^{212}$ the district court did not employ "all persons" orders, but instead attempted to control community resistance indirectly, by enjoining named persons and ordering them to prevent an undefinable class from doing acts that the court considered threatening to the desegregation judgment. Judge Garrity issued orders to local officials, in addition to school board members, directing them to take specified steps to ensure the peaceful implementation of the desegregation decree. ${ }^{213}$ This indirect method of controlling private conduct avoids several of the major infirmities of orders directed to an undefinable class. Because the court's orders are addressed only to named parties, the scope requirements of rule 65(d) are satisfied. If the officials do not comply with the court's orders, they will be subject to contempt, ${ }^{214}$ but they will have been provided notice and an opportunity to be heard. Private individuals who violate the enforcement measures adopted by local officials under the court's orders will be subject to the appropriate sanctions, but not to contempt, since the private persons are not bound to any judicial order. ${ }^{215}$ The injunction addressed to officials may be either preliminary or permanent. ${ }^{216}$ Because preliminary injunctions are

${ }^{212}$ Morgan v. Hennigan, 379 F. Supp. 410 (D. Mass.), aff'd sub nom. Morgan v. Kerrigan, 509 F.2d 580 (1st Cir. 1974), cert. denied, 421 U.S. 963 (1975), desegregation plan ordered, 401 F. Supp. 216 (D. Mass. 1975), aff'd, 530 F.2d 431 (1st Cir. 1976).

213 Judge Garrity joined the Boston School Committee, the School Superintendent, and the Mayor of Boston as parties to the desegregation suit. These "city defendants" were ordered to "see to it" that the police prevent "all gatherings of three or more people and all noisy or threatening conduct" near schools when such gatherings were likely to disrupt school activities or make students and faculty "reasonably fearful for their safety" and "all gatherings of three or more people engaged in or threatening to engage in violent conduct" along bus routes. See note 26 supra. The court also ordered the Mayor to request additional police aid from other cities and the state, and if necessary to ask the Governor for assistance from the National Guard. Id. In addition, the city defendants were ordered to prevent all unauthorized persons from entering school grounds. Id. Indirect orders were also issued in Newburg Area Council. See note 23 supra.

21s A civil contempt sanction would be imposed. Telephone conversation with the office of Judge Garrity, February 13, 1976.

${ }^{215}$ The collateral bar rule, which prevents persons who have violated an injunctive order from raising the defenses of invalidity or erroneousness of the order in a contempt proceeding, does not apply in proceedings against persons who have violated an ordinance or police order. See Shuttlesworth v. City of Birmingham, 382 U.S. 87 (1965); note 81 supra.

216 Because notice and an adversary hearing for the enjoined parties are possible, the court is not limited to TROs, which are valid only for ten days. 
issued after hearings often held on the basis of affidavits, ${ }^{217}$ relatively swift and summary action is not precluded.

In addition, the indirect regulation of community resistance is somewhat less offensive to first amendment interests than "all persons" injunctions. Hearings can be held with the named parties prior to the issuance of the court's orders, but it is unclear that such hearings result in more narrowly tailored regulation of public speech and assembly, since the local officials are unlikely to provide adequate representation for the first amendment interests of the entire community. ${ }^{218}$ The absence of the collateral bar rule is more important for the protection of first amendment interests. A member of the community can vindicate his first amendment rights by asserting the unconstitutionality of the restraints as a defense to a prosecution for violating such restraints.

Practical considerations also support the use of judicially sponsored and supervised plans to protect desegregation decrees from community resistance. A school board working alone cannot ensure that a desegregation plan will be effective. ${ }^{219}$ Busing plans in particular require the cooperation of several municipal agencies, particularly transit systems, police departments, and traffic control authorities. The best method of achieving this cooperation is judicial control and coordination of those agencies charged with regulating various kinds of private conduct.

Despite these advantages of indirect regulation, the authority of a district court to intervene in the operations of state and local agencies must be critically examined. ${ }^{220}$ It is first necessary to define

217 See 7 Moore's Federal Practice $\mid 65.04[3]$, at 65-59 to -65 (2d ed. 1975); Developments in the Law-Injunctions, 78 HARv. L. REv. 994, 1055 (1965).

21s Compare Morgan v. Kerrigan, No. 72-911-G (D. Mass., Sept. 5, 1975) (order issued after hearings with local officials, directing local officials to prevent "gatherings of three or more people engaged in or threatening to engage in violent conduct on or adjacent to any school bus . . . route . . . which makes students or bus drivers reasonably fearful for their safety"), with Newburg Area Council, Inc. v. Board of Educ., Nos 7045 \& 7291 (W.D. Ky., Sept. 6, 1976) (order issued after hearings with local officials not parties to the order requiring that "persons, more than three in number, shall not gather or assemble along any bus route in this . . . county while school buses are being operated along them").

210 Both Judge Garrity and Judge Gordon were convinced that their enforcement orders were crucial to the success of the desegregation decree. Telephone conversations with the offices of Judge Garrity and Judge Gordon, February 13, 1976.

${ }^{220}$ A threshold question is whether state and local government agencies can be sued in federal court. The Supreme Court has construed the eleventh amendment to protect a nonconsenting state from suit in federal court by one of its own citizens as well as by a citizen of another state. Hans v. Louisiana, 134 U.S. 1 (1890). In Ex parte Young, 209 U.S. 123 (1908), the Court held that a state attorney general could, in his individual capacity, be enjoined from enforcing a state law which violated the fourteenth amendment. Ex parte Young significantly reduced eleventh amendment limits on the power of federal courts to enjoin state 
the prerequisites for making a non-school board agency a party to the desegregation suit or the subject of an order designed to effectuate a desegregation decree. Once those prerequisites are determined, the limits of permissible judicial intervention in the affairs of such an agency may be discussed.

1. The Requirement of an Independent Constitutional Violation. Judicial intervention in the operation of a non-school board agency that acts affirmatively to block a school desegregation plan is not controversial. ${ }^{22}$ Because the agency has violated the desegregation plaintiff's constitutional rights, it is properly subject to the court's remedial powers. When official conduct has not directly caused a deprivation of constitutional rights, but is perceived to have allowed private citizens to interfere with the exercise of constitutional rights, a court's authority to intervene is less clear. ${ }^{222}$

officials from actions which violate constitutional rights. See K. Davis, AdMinistrative Law TEXT $§ 27.03$, at $499-500$ (1972).

Recent Supreme Court opinions have stated that the only eleventh amendment bar to suits against state officials is a prohibition of retroactive damages paid out of the state treasury; prospective injunctive relief is not prohibited. Fitzpatrick v. Bitzer, $96 \mathrm{~S}$. Ct. 2666, 2672-73 (1976) (Stevens, J., concurring); Edelman v. Jordan, 415 U.S. 651 (1974).

221 State executive officials have been enjoined from preventing the implementation of a desegregation decree. See, e.g., United States v. Barnett, 330 F.2d 369 (5th Cir. 1963), rev'd on other grounds, 376 U.S. 681 (1964); Cooper v. Aaron, 358 U.S. 1 (1958). See generally Comment, Theories of Federalism and Civil Rights, 75 YALE L. J. 1007, 1014-17 (1966).

42 U.S.C. $\$ 1983(1970)$ provides for relief against state or local officials who act to deprive any person of his constitutional right to attend public schools without regard to race.

Every person who, under color of any statute, ordinance, regulation, custom, or usage, of any State or Territory, subjects, or causes to be subjected, any citizen of the United States or other person within the jurisdiction thereof to the deprivation of any rights, privileges, or immunities secured by the Constitution and laws, shall be liable to the party injured in an action at law, suit in equity, or other proper proceeding for redress.

Under 28 U.S.C. $\$ 1343$ (3) (1970), the federal courts have jurisdiction over $\$ 1983$ suits without regard to the amount in controversy.

Although state and local officials can be enjoined under $\S 1983$, they enjoy a qualified immunity from liability for personal damages. See Scheuer v. Rhodes, 416 U.S. 232 (1974). The scope of the immunity depends on the discretion and responsibility of the office and the circumstances under which the action was taken. Id. at 247-48.

${ }_{222}$ The problem is to determine when the discriminatory actions of private citizens are linked to official action or inaction so as to constitute state action within § 1983. The state's connection with private misconduct will warrant judicial intervention when it amounts to no more than passive permission for private discrimination, see, e.g., Gilmore v. City of Montgomery, 417 U.S. 556 (1974), or use of state machinery to implement private discriminatory choices. See, e.g., Reitman v. Mulkey, 387 U.S. 369 (1967). See generally G. GuNTHER, CoNStitutional Law 915-16 (9th ed. 1975). Those cases which find state action under $\$ 1983$ all involve antecedent private discriminatory conduct. In Morgan and Newburg Area Council the basis for judicial intervention is more tenuous. Individuals who walk along bus routes in groups of more than three or who shout racial epithets are not violating anyone's constitutional rights. The only source of "state action" in police failing to stop such private conduct consists of official inaction in the face of private conduct which does not itself constitute a 
This issue is implicated by the orders in Morgan v. Kerrigan commanding the police to prevent groups of more than three persons from walking along bus routes, and by the orders in Newburg Area Council instructing the city Safety Director to withhold parade permits for a period of time. These orders were not based on a constitutional violation on the part of officials or the agencies they represent, but the courts nevertheless claimed that the officials must take specific steps in order to prevent private interference with the desegregation decree. ${ }^{223}$

Several recent cases indicate that judicial involvement in the affairs of a non-school board agency without a prior constitutional violation on the part of that agency is impermissible, and that relief tailored to the independent constitutional violation defines the boundaries of legitimate judicial involvement. In Milliken $v$. Bradley, ${ }^{224}$ the Supreme Court reversed the Sixth Circuit ${ }^{225}$ and held that a federal court may not impose a multidistrict remedy for single-district de jure school segregation. ${ }^{226} \mathrm{~A}$ cross-district remedy is conditioned on a showing that "racially discriminatory acts of the state or local school districts, or of a single school district have been a substantial cause of interdistrict segregation."227 The court found no evidence that the suburban school districts had been such a "substantial cause of interdistrict segregation," 228 and rejected a

deprivation of constitutional rights. In this context, the attenuation of the state's involvement with the deprivation of constitutional rights is extreme.

225 See notes 23 \& 26 supra.

224418 U.S. 717 (1974).

${ }_{2 z}$ Bradley v. Milliken, 484 F.2d 215 (6th Cir. 1973). The circuit court agreed with the lower court's reasoning that since the state of Michigan had been involved in maintaining segregation in Detroit schools, and all "school districts are instrumentalities of the state," a metropolitan-wide remedy was appropriate. Id. at 249-252. The Supreme Court found the evidence of state involvement insufficient for a metropolitan-wide remedy. 418 U.S. at 749 . 50 .

22a The Supreme Court had previously upheld a Fourth Circuit decision that rejected an interdistrict remedy for school segregation. In Bradley v. School Bd., 338 F. Supp. 67 (E.D. Va.), rev'd, 462 F.2d 1058 (4th Cir. 1972), aff'd by an equally divided court, 412 U.S. 92 (1973), the district court had joined two predominantly white outlying counties to its decree without requiring proof that the county boundaries had been drawn for segregative purposes or that the counties' actions rendered them responsible for the city's segregation. $338 \mathrm{~F}$. Supp. at 100. The Fourth Circuit reversed, reasoning that absent proof that "the counties were . . . keeping blacks in Richmond schools while allowing whites to flee ..." there was no indication that the county officials had acted with segregative intent and effect. 462 F.2d at 1065.

227418 U.S. 717, 744-45 (1974). The court cited Swann v. Charlotte-Mecklenburg Bd. of Educ., 402 U.S. 1, 16 (1971), for the "controlling principle . . . that the scope of the remedy is determined by the nature and extent of the constitutional violation." 418 U.S. at 744 .

${ }^{22 x} 418$ U.S. at 745,752 . The district court had stated that it had not even considered any evidence as to discriminatory actions of the suburban school districts. 345 F. Supp. 914, 920 (E.D. Mich. 1972). 
metropolitan-wide remedy despite the fact that without such a remedy effective desegregation was impossible. ${ }^{229}$ Achieving "the greatest possible degree of actual desegregation" 230 in one school district does not justify judicial intervention in the affairs of school districts that have not been implicated in a constitutional violation: "without an interdistrict violation and interdistrict effect, there is no constitutional wrong calling for an interdistrict remedy."231 Milliken thus suggests that a desegregation court lacks the authority to issue orders like those involving the police department in Morgan and the Safety Director in Newburg Area Council in the absence of constitutional violations attributable to those agencies. However, this application of Milliken is problematic, since the case was primarily concerned with preserving the autonomy of agencies in separate political units.

Boundary lines may be bridged where there has been a constitutional violation calling for interdistrict relief, but the notion that school district lines may be casually ignored or treated as a mere administrative convenience is contrary to the history of public education in our country. No single tradition in public

${ }^{229}$ Id. at 765 (White, J., dissenting); Bradley v. Milliken, 484 F.2d 215, 249 (6th Cir. 1973).

${ }^{230} 418$ U.S. at 780 (White, J., dissenting), quoting Swann v. Charlotte-Mecklenburg Bd. of Educ., 402 U.S. 1, 26 (1971).

238418 U.S. at 745 . The Court does little to clarify the distinction between "interdistrict violation" and "interdistrict effect" or to indicate what evidence will demonstrate their existence. "[A]n interdistrict remedy might be in order where the racially discriminatory acts of one or more school districts caused racial segregation in an adjacent district, or where district lines have been deliberately drawn on the basis of race." Id. It is insufficient for plaintiffs to show that de jure segregation exists in one district and that no effective desegregation plan can be devised within that district's boundaries. The presence of de jure segregation in several districts is also insufficient to establish an interdistrict violation or effect. Rather, plaintiffs must show that segregation in one district resulted from discriminatory actions by officials in the other districts or by the state authorities responsible for drawing district boundary lines.

Since Milliken, several cases have met these requirements for interdistrict relief. In Newburg Area Council, Inc. v. Board of Educ., 510 F.2d 1358 (6th Cir. 1974), cert. denied, 421 U.S. 931 (1975), the circuit court reconsidered the district court's findings in light of Milliken, and held that "the situation presented is that of two districts in the same county of the state being equally guilty in failing to eliminate all vestiges of segregation . . . "510 F.2d at 1361. The court also found a cross-district effect in the fact that black students had been bused across district lines "for the purpose of aiding and implementing continued segregation." Id. at 1360 . As in Milliken, the emphasis is on finding culpability on the part of school authorities as a condition for requiring them to participate in the remedy. See also United States v. Board of School Comm'rs, 541 F.2d 1211 (7th Cir. 1976) (affirming a desegregation plan requiring interdistrict transfer of students on a finding that the exclusion of the city school district from a state statute creating a consolidated county-wide government had confined black students to the city schools). 
education is more deeply rooted than local control over the operation of schools; local autonomy has long been thought essential both to the maintenance of community concern and support for public schools and to quality of the educational process. ${ }^{232}$

Such considerations do not apply to orders addressed to different agencies within the same political unit, like the orders in Morgan and Newburg Area Council. The Court in Milliken did not consider the circumstances in which a desegregation court could legitimately supervise agencies within the same political unit as a school board that are not vested with responsibility for the school system..$^{233}$

In Hart v. Community School Board, ${ }^{234}$ the Second Circuit reviewed a desegregation order that had included several non-school board agencies within New York City as defendants. The school board had contended that residential patterns created and maintained by city, state, and federal housing authorities contributed to racial imbalance in the schools. The housing officials were impleaded as third-party defendants. Following the principle announced in Brown v. Board of Education that school boards are legally responsible for achieving school desegregation, the district court held that liability for segregation could not be shifted to other government agencies. ${ }^{235}$ Nevertheless, the housing authorities were ordered to remain in the case and to present plans for ending residential discrimination in the area. ${ }^{236}$

The district court gave two reasons for refusing to dismiss these non-school board agencies. First, even though the agencies were not legally responsible for the school board's actions, "they are partly 'liable for' the harm, in the sense that their actions help maintain segregated schools. . . . [N]o effective decree requiring desegregation of the schools is possible without a shift in the racial composition of the tenants in the public housing controlled by third-

232418 U.S. at $741-42$.

25 State and local officials who are responsible for the segregated condition of a school system can and should be made parties to the desegregation suit. Under federal rule 19 (Joinder of Persons Needed For Just Adjudication), such officials could be joined if they are necessary to effectuate complete relief and if their absence would insufficiently protect their interests or those of persons already parties. Under federal rule 20 (Permissive Joinder), such officials could be joined if it can be shown that their actions were part of a single transaction or occurrence and raised a question of law or fact common to those already named as parties. See, e.g., Bradley v. Milliken, 433 F.2d 897 (6th Cir. 1970).

234 383 F. Supp. 699 (E.D. N.Y. 1974), aff'd with modifications, 512 F.2d 37 (2d Cir. 1975).

23538 F. Supp. at 752.

224 Id. at 753 . 
party defendants." ${ }^{237}$ The court viewed the presence of the housing officials as necessary "to insure that the court's decree is not flouted and is fully implemented." 238

Second, the district court invoked a broad notion of state responsibility for school desegregation to justify its refusal to dismiss the third-party defendants. "[T] he state is responsible for carrying out the decree of the court and it must use each of its arms . . . to effectuate desegregation of the schools." ${ }^{239}$ Relying on this principle of state responsibility, the court ordered that the other agencies that would necessarily be involved in effectuating the decree be added as parties. The Metropolitan Transit Authority, the Police Commissioner, and the Park Department were made parties to the desegregation suit and ordered to submit coordinated plans for transporting and protecting the school children. ${ }^{240}$

The district court relied on the Sixth Circuit decision in Bradley $v$. Milliken ${ }^{241}$ to join government officials who had not been found legally responsible for the segregated condition of the schools. On appeal, the Second Circuit noted the Supreme Court's reversal in Milliken and recommended the dismissal of the third-party housing authority defendants, even though they had not appealed and were willing to remain as parties. ${ }^{242}$ Because the third-party defendants had been found not liable for the constitutional violation, the court held that no case or controversy remained as to them. ${ }^{243}$ The

${ }^{237}$ Id. at 752-53.

${ }^{238}$ Id. at 753. The court "mooted" the third-party claim on the basis of "the decision that plaintiffs are constitutionally entitled to a comprehensive remedy." Id. at 754. The district court rejected the impleader as improper under federal rule 14(a), since the housing authorities were not liable to the school board for the plaintiff's claims. By "mooting" the third-party claim, however, the court was able to require the housing authorities to remain parties to the suit.

239 Id. Federal housing authorities were ordered to remain in the action because under Bolling v. Sharpe, 347 U.S. 497 (1954), they had a responsibility not to cause segregated schools. The district court also held that the federal housing authorities were in privity with the defendants, and were thus bound under rule 65(d).

$240383 \mathrm{~F}$. Supp. at $754,758$.

2st 484 F.2d 215 (6th Cir. 1973).

$212512 \mathrm{~F} .2 \mathrm{~d}$ at 56 . The basis for the housing officials' willingness to remain was their view that coordinated action would be helpful in implementing the desegregation decree.

${ }^{243} \mathrm{Id}$. at 55-56. The circuit court reasoned that by "mooting" the third-party action, the district court had effectively dismissed it. The district court had already relaxed its demands on the third-party housing authority defendants by only requiring them to submit periodic reports, noting that " $[t]$ he decretal tool is poorly designed for restructuring an entire community." 383 F. Supp. at 775.

Compare Hart v. Community School Bd., 383 F. Supp. 699 (E.D.N.Y. 1974), aff'd with modifications, 512 F.2d 37 (2d Cir. 1975), with United States v. Board of School Comm'rs, 541 F.2d 1211, 1222-23 (7th Cir. 1976) (holding that the city housing authority was properly joined to the desegregation decree when discriminatory site selection was found to have 
Second Circuit was equally concerned with what it considered an unwarranted extension of judicial power to fashion remedies for school segregation, the same problem that the Supreme Court had confronted in Milliken. ${ }^{24}$ The district court had improperly retained the third-party defendants in the suit in the absence of constitutional violations attributable to them. A district court should not be in a position to "superintend so vast a series of continuing enterprises and ... to interpose a remedy whenever [the judge] does not agree with the voluntary action undertaken by appropriate public bodies." 245

Hart suggests that Milliken's requirement of an independent constitutional violation as a predicate for judicial intervention extends to cases involving separate agencies within a single political unit. Judicial supervision of agencies that are not liable for the unconstitutional condition of the schools is not justified, even though more substantial relief would thereby be provided to remedy the harm caused by the school board's violation. ${ }^{246}$

In Hills $v$. Gautreaux, ${ }^{247}$ the Supreme Court approved a metropolitan-wide remedy in a suit in which plaintiffs claimed that the public housing system operated by the Chicago Housing Authority and financed and supervised by the Department of Housing and Urban Development was racially segregated. The Court in Gautreaux authorized a plan that included both urban and suburban political units. In contrast to Milliken, which involved numerous independent school districts, Gautreaux involved a defendant that operated on an areawide, multidistrict basis. Proceeding from

\footnotetext{
"significantly contributed to the disparity in residential and school populations between the inner city and the suburbs").

2s 512 F.2d at 55-56 \& n.25. The court expressed the fear that with supervisory authority over nonculpable agencies, "the District Court will become . . . a de facto "legislative authority' to resolve these complex questions ..." 512 F.2d at 56 n.25, quoting Milliken v. Bradley, 418 U.S. 717, 743-44 (1974).

2ts $512 \mathrm{~F} .2 \mathrm{~d} 44$ at 56.

214 The Second Circuit did not address the continuing presence in the suit of the police commissioner, recreation authority, and transit authority. Insofar as these agencies, like the housing authorities, are neither responsible for the segregated condition of the schools nor have committed acts interfering with the desegregation decree, the rationale of Hart requires their dismissal from the suit. However, the Second Circuit noted that the desegregation court could still ask the nonculpable agencies for cooperation on a voluntary basis. $512 \mathrm{~F} .2 \mathrm{~d}$ at 56 .

In Morgan v. Kerrigan, the district court included state education officials as parties to the desegregation decree. The First Circuit found that these defendants had not contributed to the segregated condition of Boston's schools, but ordered that they be retained in the suit to help in devising remedies. 509 F.2d 580, 582-83 n.4 (1st Cir. 1974). The reasoning of Hart and Milliken indicates that the state education officials should have been dismissed from the suit.
}

${ }^{217} 96$ S. Ct. 1538 (1976). 
this distinction, the Supreme Court focused on the aspects of Milliken that are relevant to the question of the prerequisites for judicial intervention in the operation of non-school board agencies.

The Court noted that Milliken was "actually based on fundamental limitations on the remedial powers of the federal courts to restructure the operation of local and state governmental entities." 248 Thus the principles expressed in Milliken go directly to the remedial powers of the federal courts, and are not limited to the "deeply-rooted tradition of local control of public schools." district court's areawide remedy in Milliken was impermissible "because it contemplated a judicial decree restructuring the operation of local governmental entities that were not implicated in any constitutional violation." ${ }^{250}$ The Court continued: "The critical distinction between HUD [in Gautreaux] and the suburban school districts in Milliken is that.HUD [which was authorized to operate on an areawide basis] has been found to have violated the Constitution. That violation provided the necessary predicate for the entry of a remedial order against HUD ...."251

These three cases suggest a standard for determining the limits of judicial power to intervene in government agencies when devising remedies for racial segregation. Milliken applies the requirement of a constitutional violation to independent school districts. Hart can be viewed as extending Milliken's requirement to judicial intervention in the affairs of non-school board agencies within a single political unit. Gautreaux reemphasizes that an independent constitutional violation on the part of an agency is a necessary predicate for judicial intervention. ${ }^{252}$

248 Id. at 1544 .

249 Id. at 1544-45 \& n.11.

$250 \mathrm{Id}$. at 1545 .

${ }^{251}$ Id. at 1546. The Court found that metropolitan-wide relief against HUD could be tailored to avoid impermissible interference "with local governments and suburban housing authorities that have not been implicated in HUD's unconstitutional conduct." Id. at 1547. Suburban municipalities would not be required to submit proposals to HUD and would retain the right to insist on conformity with zoning and other land use restrictions. Such an order would not "consolidate or in any way restructure local governmental units." Id. at 1550 . See also United States v. Board of School Comm'rs, 541 F.2d 1211, 1222-23 (7th Cir. 1976) (enjoining housing authorities from future construction of public housing in the city school district).

$25296 \mathrm{~S}$. Ct. at 1550. An earlier stage of the Gautreaux case provides an analogous example of this principle. In Gautreaux v. Romney, 457 F.2d 124 (7th Cir. 1972), the court reversed an injunction which terminated Model Cities Program funds for Chicago in an effort to "bring pressure to bear" upon the Chicago Housing Authority to comply with an order concerning selection of housing sites. The Seventh Circuit held that it was improper for a district court to threaten termination of federal funds to a program which had not been proven discriminatory in order to remedy discrimination in a different program, stressing the unto- 
In Milliken the Supreme Court expressed the fear that a court could not ascertain the limits of permissible judicial intervention without an identifiable violation to repair, and that without such limits the court might resemble a "legislative authority."253 The existence of a constitutional violation authorizes judicial intervention in the first instance. This prerequisite is also the standard that measures the appropriate degree of involvement. "Once a constitutional violation is found, a federal court is required to tailor 'the scope of the remedy' to fit 'the nature and extent of the constitutional violation." "254

2. The Scope of Permissible Judicial Intervention. The orders directed to the police in Morgan can be analyzed in terms of the interaction of the predicates for and scope of judicial intervention in the operations of non-school board agencies. ${ }^{255}$ If the police were to prevent black school children from entering schools, thus directly frustrating a desegregation decree, the court could unquestionably intervene to prevent this interference. If the police were to make no effort to protect school children from known private violent resistance, the court could order the police to ensure that the students could safely attend desegregated schools. ${ }^{256}$ In Morgan, however, the court sought to supervise the police despite the absence of active or passive police misconduct interfering with school desegregation. Judicial supervision was premised on the court's belief that certain private conduct which was not prohibited by statute or ordinance should be controlled. ${ }^{257}$ However, examination of the requirement of an independent constitutional violation as a predicate for judicial intervention indicates that the court in Morgan had no such supervisory authority. The court mistakenly equated its power to inter-

ward effects that would result from such pressure tactics. Such effects, particularly the detriment to innocent beneficiaries of nonculpable programs, were also present in Milliken and were an important factor in that decision. See Hills v. Gautreaux, 96 S. Ct. 1538, 1545 (1976).

253418 U.S. $717,743-44$ (1974).

254 Hills v. Gautreaux, 96 S. Ct. 1538, 1544 (1976), citing Swann v. CharlotteMecklenburg Bd. of Educ., 402 U.S. 1, 16 (1971).

255 This discussion emphasizes orders to police as the most significant and likely means for desegregation courts to control indirectly the conduct of the community. See, e.g., Hart v. Community School Bd., 383 F. Supp. 699, 758 (E.D.N.Y. 1974). For examples of cases in which courts have ordered the police to protect persons exercising their constitutional rights, see Smith v. Ross, 482 F.2d 33 (6th Cir. 1973); Belknap v. Leary, 427 F.2d 496 (2d Cir. 1970); Huey v. Barloga, 277 F. Supp. 864, 873 (N.D. Ill. 1967); Williams v. Wallace, 240 F.Supp. 100 (M.D. Ala. 1965). Deliberate official refusal to protect persons asserting constitutional rights constitutes a violation of 18 U.S.C. $\$ 242$ (1970). See, e.g., Lynch v. United States, 189 F.2d 476, 481 (5th Cir. 1951); Catlette v. United States, 132 F.2d 902, 907 (4th Cir. 1943).

${ }^{257}$ See text and notes at notes 22 \& 26 supra. 
vene with its power to enforce all the measures it perceived to be necessary to protect the implementation of the school desegregation judgment. Morgan thus implicitly adopted the principle disapproved in Milliken, that "complete relief" defines the scope of judicial power in enforcing school desegregation.

Even if the police had violated the rights of the desegregation plaintiffs, the validity of the Morgan court's remedial orders would be doubtful. For example, in ordering that the Mayor "see to it" that the police prevent gatherings of more than three persons along the school bus routes, the court was not merely commanding the police to enforce laws against breach of the peace or loitering, but was instructing them to take specific steps to regulate private conduct. It is unlikely that a court can legitimately remedy a discriminatory failure to enforce the laws by giving detailed instructions as to the manner of enforcement.

Several cases have considered the permissible degree of judicial supervision of police operations when a court is fashioning a remedy for a constitutional violation. The Supreme Court first approved the use of injunctions as a remedy for unconstitutional police conduct in Hague $v$. CIO. ${ }^{258}$ In this case the district court permanently enjoined the Mayor, the Police Chief, and other city officials from continuing their "deliberate policy" of preventing plaintiffs from engaging in labor union organizational activities. The defendants had acted pursuant to ordinances regulating public meetings and prohibiting leafleting. The district court enjoined the enforcement of these laws on first amendment grounds and instructed the defendants as to the condition under which leafleting and public meetings were to be allowed. The Court affirmed the injunction, but modified its terms. "[T] nance is void, the respondents are entitled to a decree so declaring and an injunction against its enforcement... . The court cannot rewrite the ordinance...." 259

In Allee $v$. Medrano, ${ }^{260}$ the Supreme Court affirmed an injunction against a "persistent pattern of police misconduct" ${ }^{261}$ which had intimidated the plaintiffs in the exercise of their constitutional rights. The injunction had issued only after a showing of a persistent and pervasive pattern of misconduct, ${ }^{262}$ and did "no more than re-

\footnotetext{
${ }^{258} 307$ U.S. 496 (1939).

250 Id. at 518 (opinion of Roberts, J.).

280416 U.S. 802 (1974).

26I Id. at 815. See also Lankford v. Gelston, 364 F.2d 197 (4th Cir. 1966).

262 "Isolated incidents of police misconduct under valid statutes would not . . . be cause
} 
quire the police to abide by constitutional restraints." ${ }^{263}$ The district court was not involved in a detailed supervision of police operations. ${ }^{264}$

In Rizzo v. Goode ${ }^{285}$ the Court reaffirmed the importance of limiting judicial supervision of police operations to that necessary to remedy specific constitutional violations. The Mayor, the Police Commissioner, and the City Managing Director of Philadelphia were charged with authorizing, encouraging, and failing to prevent the misconduct of unnamed police officers. The district court found that the named defendants had not developed a policy of violating the rights of the plaintiff classes, but did find enough violations to justify a court-ordered plan for the processing of citizens' complaints by the police and for overhauling police disciplinary procedures. Authority for this remedy was grounded in the assertion that a federal court's power to "supervise the functioning of the police department . . . is firmly established." ${ }^{265}$ The Third Circuit affirmed, with modifications. ${ }^{267}$ The Supreme Court reversed as to both the finding of a violation warranting court intervention and the scope of relief granted. ${ }^{288}$ The grounds for reversal raise serious questions about the validity of the type of orders issued in Morgan $v$. Kerrigan to control police operations.

The first ground for reversal was the absence of a justiciable case or controversy between the named plaintiffs and defendants. ${ }^{269}$ The incidents of police misconduct were not shown to be directly chargeable to the named defendants. The district court had found that the "sole causal connection" between the defendants and the named plaintiffs was that future instances of police misconduct might well occur unless internal police regulations were changed. ${ }^{270}$ Because the named plaintiffs were unable to show that they would be victims of future police misconduct, the Supreme Court held that

for the exercise of a federal court's equitable powers." Allee v. Medrano, 416 U.S. 802, 815 (1974).

${ }^{223}$ Id. at 814.

264 Even where a continuing pattern of police misconduct has been found, federal courts have sought to avoid "unnecessary interference with the daily operations of the police." See, e.g., Calvin v. Conlisk, 520 F.2d 1 (7th Cir. 1975) (dismissal reversed in part), vacated and remanded, 424 U.S. 902, dismissal aff'd, 534 F.2d 1251 (7th Cir. 1976).

263423 U.S. 362 (1976).

241 Council of Organizations v. Rizzo, 357 F. Supp. 1289, 1320 (E.D. Pa. 1973).

${ }^{267}$ Goode v. Rizzo, 506 F.2d 542 (3d Cir. 1974).

2ax Rizzo v. Goode, 423 U.S. 362 (1976).

26I Id. at 371-73.

270 Id. at 371. 
the named plaintiffs lacked the requisite "personal stake in the outcome." 271

The second ground for reversal was the Court's interpretation of section 1983. ${ }^{272}$ The plaintiffs had argued that since citizens had a right to be free from unconstitutional abuses of police power, supervisory officials had a corresponding duty to minimize the incidence of such abuses. Claiming a default of this duty on the basis of statistics concerning the number of police abuses, the plaintiffs asserted a right to broad equitable relief against supervisory officials. ${ }^{273}$ The Supreme Court rejected this application of section 1983, relying on Swann v. Charlotte-Mecklenburg Board of Education. The majority viewed the plaintiffs' argument as an impermissible attempt to construe section 1983 to encompass vicarious liability based on respondeat superior. The Swann principle that "judicial powers may be exercised only on the basis of a constitutional violation" was interpreted to require a constitutional violation committed through the deliberate acts of responsible authorities. ${ }^{274}$ Such an interpretation precludes attributing responsibility to supervisory officials on the basis of the misconduct of individual officers who on their own initiative deprive individuals of their constitutional rights. ${ }^{275}$

Principles of separation of powers and federalism were invoked to support this interpretation of section 1983. The Court accepted "the well-established rule that the Government has traditionally been granted the widest latitude in the "dispatch of its own internal affairs.' "276 This principle of judicial restraint was combined with notions of federalism to support the rejection of the district court's assertion of a "firmly established" power to supervise the functioning of a local police department. ${ }^{277}$ The Court found that the limits on federal court interference in state judicial proceedings "have applicability" to federal injunctions against state and local execu-

271 Id. at 372-73. The standing requirements articulated in Rizzo were applied in Calvin v. Conlisk, 534 F.2d 1251 (7th Cir. 1976), to preclude injunctive relief against supervisory police authorities based on " "hypothetical' complaints about what some unknown policeman "might do to [the plaintiffs] in the future . . . ." Id. at 1252.

272423 U.S. at 376-79.

273 Id. at $375-76$.

${ }^{274}$ Id. at 377, quoting Swann v. Charlotte-Mecklenburg Bd. of Educ., 402 U.S. 1, 16 (1971).

${ }_{275}$ Recourse was limited to suits against individual policemen whose conduct had violated citizens' constitutional rights.

${ }_{278} 423$ U.S. at 378-79, quoting Sampson v. Murray, 415 U.S. 61,83 (1974).

$m 423$ U.S. at 381. 
tive agencies as well. ${ }^{278}$ The opinion did not specify the extent to which these limits would apply, but a deliberate policy on the part of supervisory officials that deprives individuals of their constitutional rights would presumably overcome the limits that notions of federalism impose on judicial intervention. Principles of federalism would remain important in framing relief so as not to impinge unnecessarily on discretionary decisions by the agency heads. ${ }^{279}$

In Hart v. Community School Board, as in Morgan, there was no showing of a deliberate policy of providing inadequate or unequal protection from private resistance to desegregation. Applying the principles articulated in Rizzo, it is clear that there was no case or controversy as to the police department; the Police Commissioner should not have been joined in the suit. In Morgan v. Kerrigan the Mayor was ordered to direct the police to prevent certain private conduct. Under Rizzo, neither the Mayor nor police officials could have been subjected to such an order absent a showing of constitutional violations attributable to them. Furthermore, requiring the police to take specific steps to protect the implementation of the desegregation decree conflicts with the principles of federalism that Rizzo insisted should limit the scope of remedial measures. Interference with police discretion is impermissible absent a showing of an affirmative link between the use of that discretion and a deprivation

273 The principles that have traditionally guided the federal courts in balancing the national policy of abstaining from interference in pending state court proceedings with the special federal responsibility for protecting persons from unconstitutional state action have recently undergone swift change. See Huffman v. Pursue, Ltd., 420 U.S. 592 (1975); O'Shea v. Littleton, 414 U.S. 488 (1974); Mitchum v. Foster, 407 U.S. 225 (1972); Younger v. Harris, 401 U.S. 37 (1971); Samuels v. Mackell, 401 U.S. 66 (1971); Dombrowski v. Pfister, 380 U.S. 479 (1965). See generally Note, Younger Grows Older: Equitable Abstention in Civil Proceedings, 50 N.Y.U.L. REv. 870 (1975).

It is unclear which principles from the abstention cases the Court in Rizzo applied to judicial intervention in state and local executive agencies. After Rizzo, considerations of "Our Federalism" require a court to consider whether a showing of bad faith is necessary in every case involving challenges to state and local executive agencies. Younger v. Harris, 401 U.S. 37, 44 (1971). Courts must also determine whether the plaintiffs have less drastic means available for redress, and whether great, immediate, and irreparable harm is threatened. Id. Unless these conditions are satisfied, federal injunctive relief is not warranted.

279423 U.S. at 379-80. See also Williams v. Wallace, 240 F. Supp. 100 (M.D. Ala. 1965), where the court ordered the police to provide full protection to participants in a civil rights march that had been authorized by a court order. Even though judicial intervention was warranted by the manifestations of police hostility to the marchers, the court did not instruct the police as to specific steps they should take to protect the marchers; this was left to the discretion of the police. In Wolin v. Port Auth., 392 F.2d 83 (2d Cir. 1968), the police had prevented the plaintiffs from passing out leaflets. The court ordered the police to protect the plaintiffs in their exercise of first amendment rights, but noted that "the law enforcement officers must be permitted to exercise judgment in maintaining order." Id. at $94 \mathrm{n} .16$; see text and notes at notes 258-59 supra. 
of constitutional rights.

These limits on judicial authority over the police or other local agencies do not significantly weaken the enforcement powers of district courts in desegregation suits. A court is still free to offer suggestions and request voluntary cooperation in implementing its decree. ${ }^{2 \times 0}$ If the police fail to protect constitutional rights as a result of a deliberate policy, then section 1983 warrants equitable relief. But when private conduct not in itself discriminatory or unlawful presents only a potential for the deprivation of constitutional rights at some future time, ${ }^{281}$ no affirmative duty to prevent such conduct arises. Recent Supreme Court decisions indicate that a court should not be in a position either to create such a duty or to determine how it should be fulfilled.

Morgan and Newburg Area Council can be distinguished from the cases analyzed above. Unlike the suburban school districts in Milliken, the police and the Safety Director have a duty to aid the city school board's desegregation efforts by maintaining order. Unlike the remedial orders disapproved by the Court in both Milliken and Rizzo, the orders involving the police in Morgan and the Safety Director in Newburg Area Council did not restructure the internal affairs of the local agencies. ${ }^{282}$ However, these distinctions may not overcome the rule emerging from the Supreme Court's decisions: an independent constitutional violation is a necessary predicate of judicial intervention and defines the scope of permissible remedial measures. The question raised, but not yet resolved, is the extent to which the Court will apply these requirements. Until the Court defines the limits of its holdings, the legitimacy of orders like those issued in Morgan and Newburg Area Council remains in doubt.

\section{Conclusion}

Congress and the federal courts have both responded to the persistent problem of community resistance to school desegregation. The congressional response was to enact sections 245 and 1509 of the Federal Criminal Code. Neither these statutes, nor the laws they were designed to supplement, proscribe all private conduct that interferes with the right to attend desegregated schools. The judicial

2xa See, e.g., Hart v. Community School Bd., 512 F.2d 37, 56 (2d Cir. 1975) (although the district court cannot retain jurisdiction over nonculpable officials, the court may ask them for help on a "voluntary basis").

2xi See note 222 supra.

${ }_{2 \times 2}$ Cf. Hills v. Gautreaux, 96 S. Ct. 1538, 1550 (1976) (injunction authorizing interdistrict relief would not "consolidate or in any way restructure local governmental units"). 
response, however, has exhibited less restraint. In attempting to regulate conduct beyond the reach of these statutes, courts have sought to enjoin the "undefinable class" of potential resisters to school desegregation decrees by issuing orders addressed to "all persons." These orders endanger the values protected by the statutory limits on the exercise of equitable power and by the first amendment. Attempts to regulate community resistance by enjoining local agencies that have not committed any constitutional violations may also exceed the limits on equitable power suggested by recent $\mathrm{Su}$ preme Court decisions.

Although community resistance remains a difficult problem, the judicial perception of the need for expanded equitable powers to protect desegregation decrees is unwarranted. Sections 241, 245, and 1509 , together with injunctions properly issued against named parties, afford substantial protection to the constitutional right to attend desegregated schools. Judicial fears of community resistance to school desegregation must not be allowed to create an exception to fundamental equitable principles.

H. J. Escher Lee Hyman Gudel 